\title{
MILK PRODUCTION AND DISTRIBUTION IN NINE WESTERN STATES IN THE 1950s
}

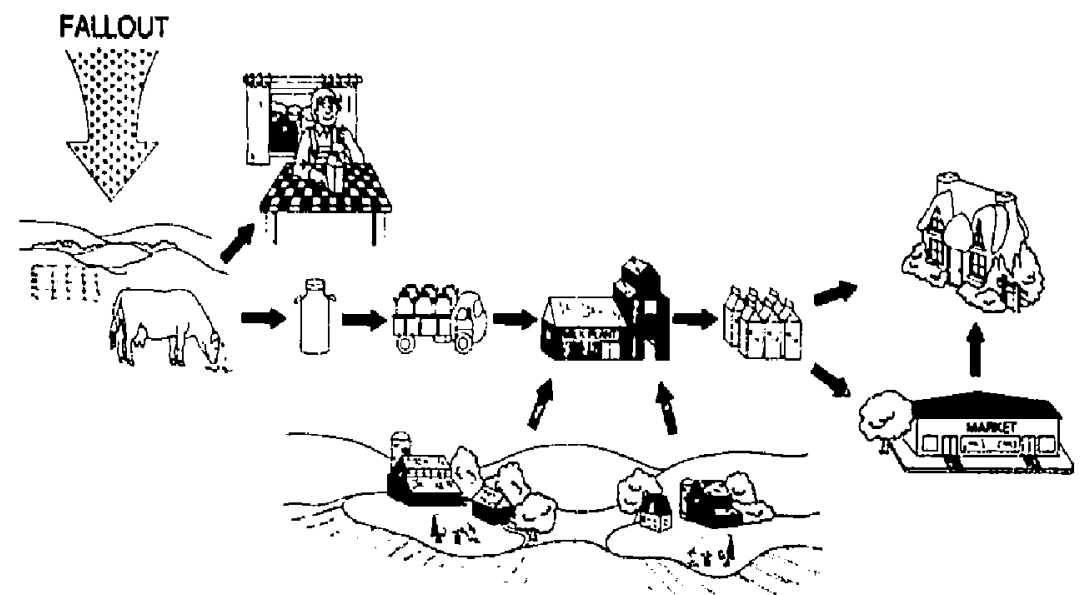

Gerald M. Ward

Department of Animal Sciences

and

F. Ward Whicker

Department of Radiology and Radiation Biology

Colorado State University

Fort Collins, CO 80523

March 1987 


$$
\text { UCRL--15907 }
$$

\section{MILK PRODUCTION AND DISTRIBUTION \\ IN NINE WESTERN STATES IN THE 1950s}

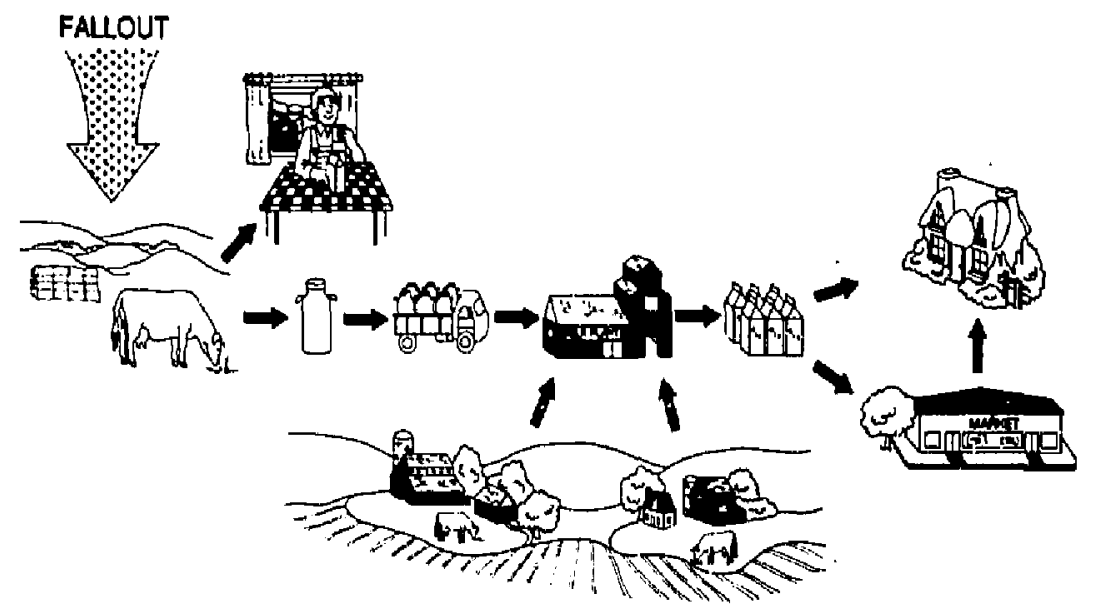

A Study Conducted for the U.S. Department of Energy, Nevada Operations Office, Las Vegas, NV and Lawrence Livermore National Laboratory Livermore, CA

by

Gerald M. Ward

Department of Animal Sciences

and

F. Ward Whicker

Department of Radiology and Radiation Biology

Colorado State University

Fort Collins, CO 80523

March 1987

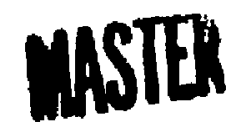

DISTFIBUTION OF THIS DOCUMENT IS URLIMITED 


\section{PREFACE}

This report is a combination of two efforts to reconstruct the historical milk-distribution networks in the vicinity of the Nevada Test site. The first effort was carried out through a contract between the Colorado State University and the Nevada Operations Office of the Department of Energy (Contract DE-ASOB-79NV10057); it focused on the Phase I area (the State of Nevada and parts of the States of Arizona, Utah, and California). The second was carried out through a personal services agreement between Dr. Geraid hard and the Lawrence Livermore National Laboratory (P.O. No. 8488205) under the auspices of the

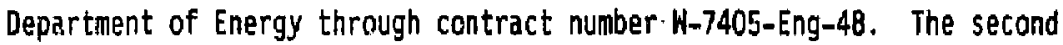
part focused on the Phase II area (the State of Utah and parts of the States of Oregon, Idaho, Hyoming, Colorado, New Mexico, Arizona, and California). As the data for the two regions were interdependent this report combines the results of both studies into a single report for convenience.

\section{DISCLAIMER}

This report was prepared as an account of work sponsored by an agency of the United States Government. Neither the United States Government nor any agency thereof, nor any of their employees, makes any warranty, express or implied, or assumes any legal liability or responsibility [or the accuracy, completeness, or uselulness of any information, apparatus, product, or process disclosed, or represents that jts use would not infringe privately owned rights. Relerence herein to any specific commercial product, process, or service by trade name, trademark, manulacturer, or otherwise does not necessarily constitute or imply its endorsement, recommendation, of favoring by the United States Government ve any agency thereof. The views and opinions of authors expressed herein do not necessarily state or reflect thrse of the United States Government or any agency thereor. 


\section{TABLE OF CONTERTS}

Page

INTRODUCTIOH

GENERAL PERSPECTIVE AND APPROACH

RESULTS AND DISCUSSION

Phase I

Southwest Utah

Hestern Nevada

Southern Nevada

Eastern Mevada

Northern Arizona

Eastern California

Phase II

Utah

Arizona

California

Colorado

Idaho

New Mexico

Oregon

Wyoming

SUMMARY

ACKNONLEDGEMENTS

TABLES

Table 1. Southwest Utah, Phase I, Milk Production and Distribution

Table 2. Western Nevada, Phase I, Milk Production and Distribution

Table 3. Southern Nevada, Phase I, Milk Production and Distribution

Table 4. Eastern Mevada, Phase I, Milk Production and Distribution

Table 5. Northern Arizona, Phase I, Milk Production and Distribution 33

Table 6. Eastern California, Phase I, Milk Production and Distribution

Table 7. Utah, Phase II, Milk Production and Distribution

Table 8. Out-of-state sales of fluid milk from Utah in 1952 and 1957 (milk equivalent, 000 's lbs.)

Table 9. County contributions to the milk supply of the three major cooperatives in Utah, and contributions of the cooperatives to the Utah Pool

Table 10. County contributions to the Utah milk pooT

Table 11. Average pasture and hay intake for cows producing milk for the Utah Pool

Table 12. Arizona, Phase II, Milk Production and Distribution

Table 13. California, Phase II, Milk Production and Distribution 


\section{TRBLE OF CONTENTS (continued)}

$\underline{\text { Page }}$

Table 14. Colorado, Phase II, Milk Production and Distribution 47

Table 15. Idaho, Phase II, Milk Production and Distribution, 49

Table 16. New Mexico, Phase II, Milk Production and Distributiun

51

Table 17. Oregon, Phase II, Milk Production and Distribution

52

Table 18. Wyoming, Phase II, Milk Production and Distribution

APPENDICES:

Appendix 1. Some Characteristics of Dairy Food Technology of Significance to Food Chain Assessment

Appendix 2. Sources of Information by State

61 


\section{IKTROOUCTIOH}

This report provides information on milk distribution and dairy cattle feeding practices in Nevada, Utah and portions of seven other adjacent states during the 1950s. The information was gathered to support the U.S. Department of Energy's "Offsite Radiation Exposure Review Project (ORERP)." This project is charged with providing radiation dose estimates for residents of Nevada, Utah, and surrounding states from nuclear weapons testing conducted at the Nevada Test Site from 1951 through 1962. The information on milk production and distribution is essential for assessment of the internal organ doses received by people as a result of ingesting radioactive falloutcontaminated foods. The information is used as input data for colorado State University's PATHMAY computer code which estimates the ingestion of twenty radionuclides by people relative to a given level of fallout deposition.

\section{GEMERAL PERSPECTIVE AND APPROACH}

A major factor in interna] radiation dose assessment is radioactivity in milk which results from exposure of dairy cattle feed to fallout. In the case of short lived radionuclides (e.g., radioiodine), the only significant transport vector to milk is fresh pasture grass or green-chopped forage. Thus, to estimate the concentration of fallout radionuclides in milk it is necessary to understand dairy feeding practices, as we11 as the milk distribution network for the area in question. 
The geographic region most subject to fallout from the Nevada Test Site includes a large area of the western United States, but it is a region with very little farm land. Most of the region consists of intermountain deserts, arid grazing lands or high mountain pastures and forests. Dairy farming and milk production in this region is found only in the irrigated yalleys which represent a small fraction of the total area. Arid grazing lands cannot provide sufficient nutrients to support milk production. Dairy farming is not located in areas of high mountain pastures because the grazing season is too short and many of these areas are not readily accessib]e. In the period of interest (1950-1962), irrigated pastures were a major source of feed for dairy cows in some, but not all, areas.

The simplest case for evaluating radionuclide intake to people via milk contaminated by fallout is the situation where cows consume all of their feed from pasture, and people consume ajlk from a single, local source. This was the actual situation for many farm and rural families. However, the majority of the population was dependent upon commercial supplies of bottled milk and other dairy products. These supplies were provided by distributors who often pooled the milk from many dairy herds located in the region. Feeding practices were in a dynamic state of change during the period 1951-1962. For instance, pasture is of almost no significance for cormercial dairy cattle feeding today in the U.S. Cows are confined to dry lots and fed almost entirely on dry feeds. As a result of changes since 1951-1962, a description of present day dairy practices has little value for evaluating conditions in former years. 
In order to estimate the contribution of fallout-contaminated pasture to radionuclide concentrations in milk, it was necessary to define the pasture season and especially the date when cows first go to pasture in the spring. Pasture forage was not usually the only source of feed for cows during the grazing season and it was therefore essential to estimate the dry matter intake from both pasture and other feeds. Hay is a major feed source that is usually produced on the dairy farm, but in some cases hay was produced in other regions and shipped to the dairy farms. Hay can be a major source of Tonger-lived radionuclifies and thus it was important to determine hay harvest dates. The same is true of alfalfa and corn or sorghum silage when these feeds are an important part of the feeding program.

For the short-lived radionuclides, the elapsed time between milk production on the farm and consumption in the home is an important parameter since radioactive decay can significantly reduce the contamination levels during the period of storage.

Unfortunately, little of the necessary data could be found in statistical tables or written form. The data base could only be established by interviews with knowledgeable people such as farmers, dairy plant operators, agricultural extension agents, and facuity of agricultural colleges. A general consensus may be developed from the interviews which represents an average for a region within some time frame. This was the approach taken to gather the information contained herein. A problem with this approach is that memory for details of 30 years ago is subject to considerable uncertainty and this is particularly a problem when dealing with changing practices. The information gathered from the geographic area of interest has been 
described separately for each region, and a list of people interviewed is provided in Appendix 2.

Various factors affect concentrations of radionuclides in milk and many of these changed during the period of interest. For example, variation existed from year to year in the time of first and last days on pasture due to changes in climatic factors such as rainfall and temperature. A gradual change which occurred nearly everywhere through the 1950s and 1960s was decreasing use of pasture, sometimes substituted with green-cut alfalfa, but more often with hay, silage and grain. The change in feeding practices to more hay and concentrates substantially increased milk output per cow and this resulted in a more uniform production throughout the year instead of the peak observed when cows are first put on pasture in the spring. Further, in the mid- to late1950s, most dairy farms were forced to convert from daily to everyother-day pick up as processors stopped picking up cans and began collecting milk in tank trucks. This was a period of consolidation of small dairies into larger marketing cooperatives and larger, more centralized processing plants. These plants changed from daily processing to two or three days per week. Home delivery changed from every day (except Sunday) to two or three days per week. The length of time bottled milk remained in the retail store increased because of lower bacterial content. The net result of all these changing practices was a longer period between milking and consumption.

The factors such as declining pasture use and increased elapsed time between production and consumption had the result of reducing radioiodine and other short-lived radionuclides in milk at the time of consumption. The changes in farm and distribution practices generally 
reduced human exposure to radioactivity. Although the changes in technology listed above are well-known, it has been very difficult to assign precise dates and quantities for most locations. Tempora] estimates are at best accurate to within only a year or two.

The problem addressed in this report is that of estimating, for specific geographic locations, the sources of milk traced back to the locations of all contributing cows, and types and sources of feed for these cows. The dietary percentages were es:imated as a function of time of year, as well as the percentages of the milk flow from each geographic source. In addition, the nominal delay time between grazing and consumption was estimated for each source. The general concept of radionuclide transport from feed to milk to consumer is illustrated in Fig. 1.

This study considered milk production and distribution in two geographic regions called Phase $I$ and Phase II. Phase I includes counties near the Nevada Test Site (NTS) for which fallout deposition data were available by comunity (Fig. 2), In addition to specific communities, each county has a "Rural" category to include residents of the county who were not living in one of the designated communities. Phase II includes areas more distant from the NTS than Phase I /Fig. 2). In Phase II the smallest geographical units considered are counties because the fallout data could not be estimated any more precisely than on a county basis. Within counties, the data were summarized by the categories rural $(<2,000$ people $)$, town $(2,000-25,000)$ and city $(>25,000)$.

The data categories needed for the PATHWAY Model, and addressed in this report, are described below. 


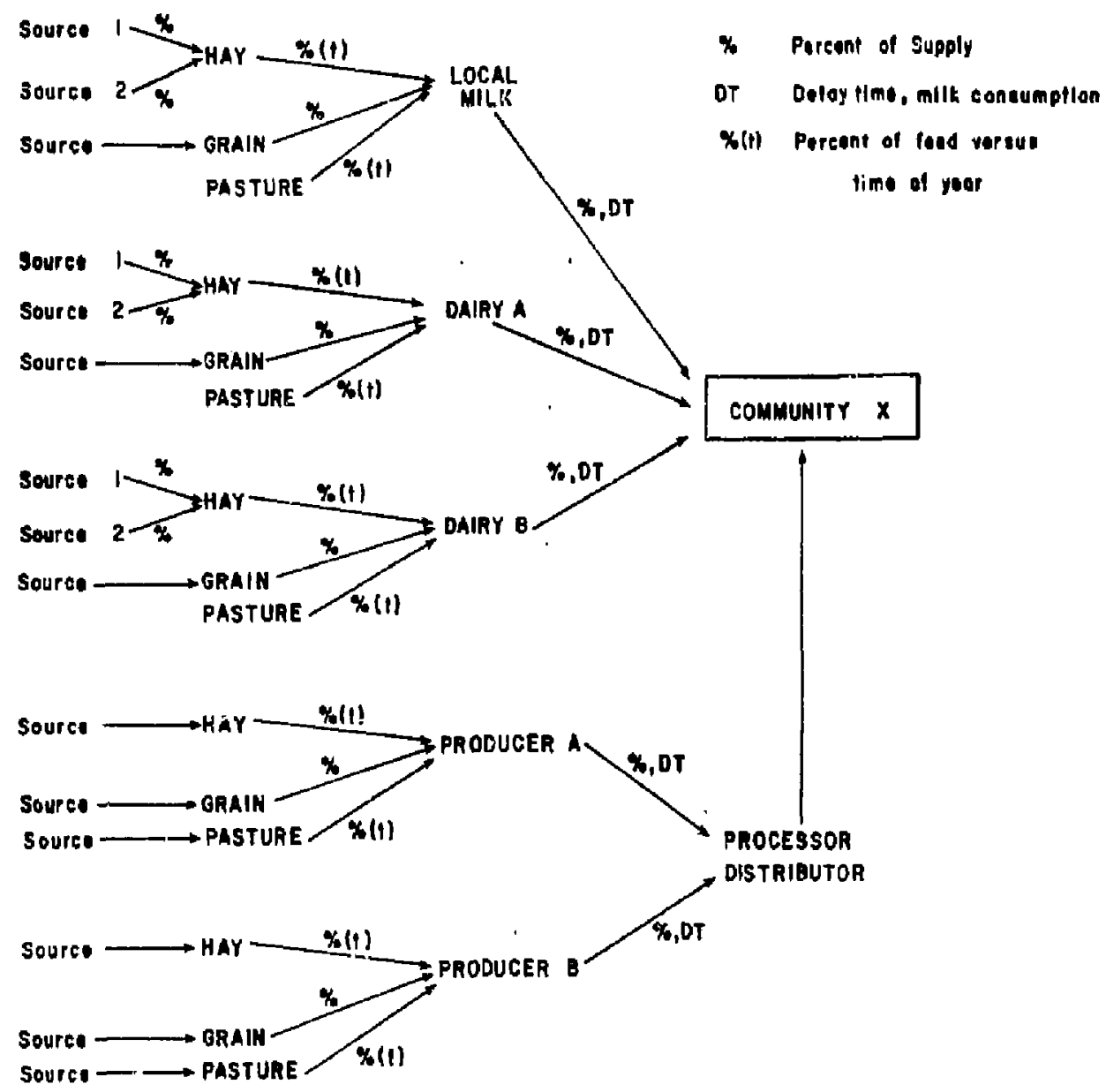

Fig. 1. Conceptual diagram of radionuclide transport from dairy cattle feed to human consumers through the milk network. "Source" refers to the geographic ared where a particular feed was grown. 


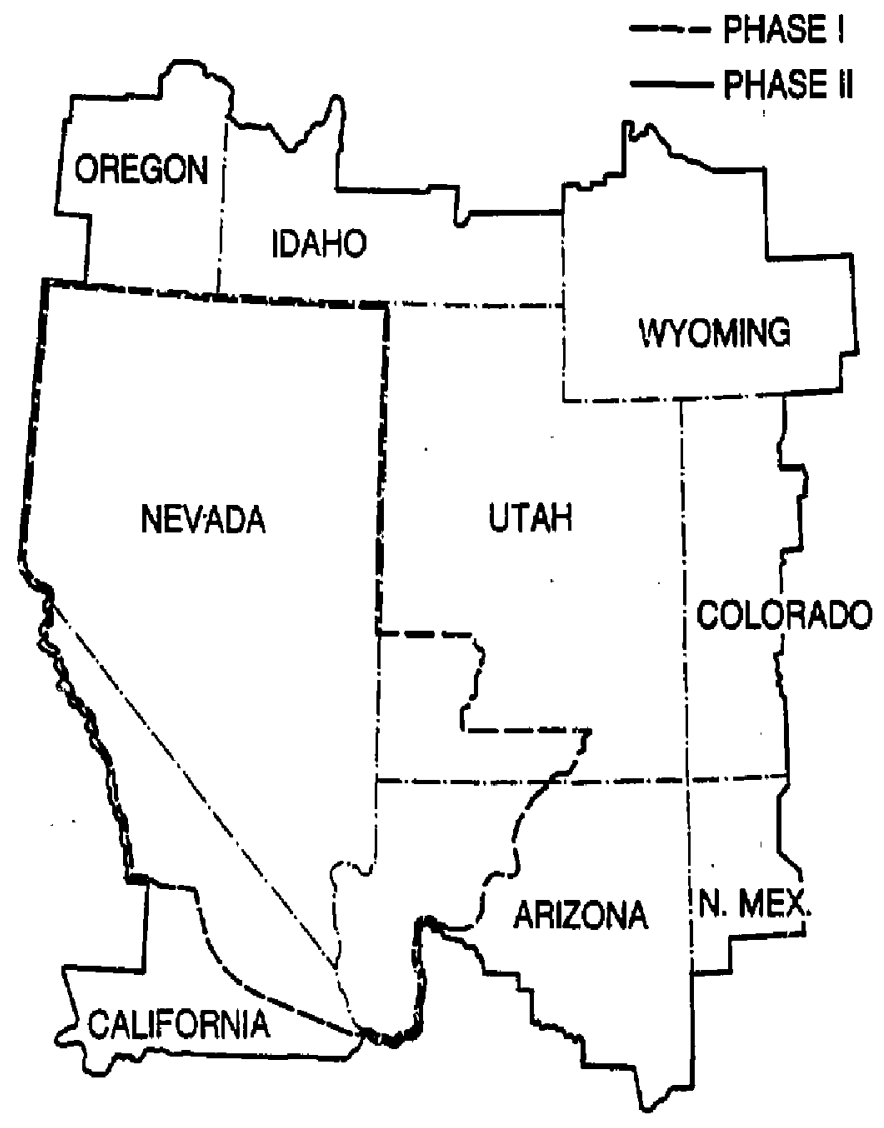

Fig. 2. Geographical boundaries of the Phase I and Phase II regions as defined by the Offsite Radiation Exposure Review Project of the U.S. Department of Energy. 
Milk source. In those areas where farming, and especially irrigated farming, was a primary enterprise, it was considered that all milk for the rural population was produced locally. That is, milk was produced locally on the farm, obtained from a neighboring farm or from local dairies that obtained milk from nearby farms. In desert areas and mining communities, residents would have depended upon bottled milk from a commercial dairy. The larger dairies collected milk from many dairy herds and distributed bottled milk throughout the region. Some of the milk distribution patterns were complex, especially in the state of Utah.

Time on Pasture. The calendar dates when cows were placed on pasture each spring were estimated for each community or community type within a county. These estimates are general averages, but it is certain that dates varied by farm and by years due to weather conditions. Cool weather can delay the start of pasture feeding by as much as two weeks. Some dairymen restricted pasture use during a wet spring because the cow's hooves would have damaged the turf, All of the pastures in the region of interest were provided surface or flood irrigation, but spring rains were usually sufficient for early growth. The general practice was to accustom cows to pasture over a weak or so in the spring with the result that pasture consumption actually did not reach the stated intake inmediately.

Hay cutting. The number of cuttings each season varied from two to six, with three being the most cormon. The dates for two cuttings were about July 1 and August 15; and for three cuttings about June 15, August 1 and September 10. Four cuttings were scheduled approximately June 1 , July 15, August 30, and October 1. Five cuttings were scheduled May 1, 
June 15, July 20, September 1 and October 5, For six cuttings per year, an additional cutting was made about Aprit 1.

Feed intake. Data on pasture and green feed consumption are expressed as $\mathrm{kg}$ of dry matter per day per cow. Green feed, including "greenchop," was usually not an important source of feed in most of the areas included. During the non-pasture season, the dry matter intake from pasture and green feed was replaced by hay, which in almost all cases was alfalfa. Corn silage supplied some of the feed, espectally in the winter, but it was not a quantitatively important source of feed except in the St. George area and in Clark County Nevada. Concentrates such as corn, barley and protein supplements were not included in this analys is because, to a large extent, they were not produced on the farm and of ten were produced outsice the county or even outside the state. Considerable quantitities of these concentrates were produced in eastern Colorado, California, Oregon, and Idaho. In the PATHKAY mode T, tt was assumed that all cows received $3 \mathrm{~kg}$ of grain daily thruughout the year.

Delay time. Delay time was estimated as the elapsed time between grazing and milk consumption; thus it included the time between grazing and milking. Typically, cows were put out to pasture after milking, and then milked again in the evening. They returned to pasture in the evening and then may or may not have grazed in the morning before milking. Some time after the morning milking, the milk cans were picked up and hauled to a dairy plant. After bulk tanks appeared in about 1958, the milk was picked up every other day. After milk arrived at the dairy plant, it might have been pasteurized and bottled that day or on the following day (but not on Sunday). Milk was delivered to the home, usually early in the morning the day after processing. The milk would, 
on average, be consumed during the next 24 hours because milk was delivered every day except Sunday in the early 1950s. Milk was stocked in stores about one or two days after processing. Siarting in about 1958, the frequency of store and home deliveries decreased. This was more efficient and feasible because the milk had a lower bacterial content and thus a longer shelf life. 


\section{RESULTS AND DISCUSSION}

\section{Phase I}

The communities listed for Phase I are divided into șin groups. Data on milk production practices and distribution for the PATHWAY model are presented in Tables 1-6.

Southwest Utah

Southwestern Utah was an area of particular interest because certain portions of it received relatively heavy fallout. The residents were generally supplied by locally produced milk (Table 1), although some boitled milk from near. Salt Lake City was used after about 1957. Some milk was shipped to Las Vegas and a small anount was shipped to the Salt Lake City area for processing and distribution. Pasture use varied considerably within this area. Enterprise was a major hay production center which provided feed for other areas in the region. Milk bottled in Cedar City was shipped to several nearby comanities. Minersville was a significant source of raw milk for the Cedar City dairies. Hestern Nevada

Residents of this area obtained essentially all of their milk from production within the region. A regional milk pool e; isted, which is referred to as the West Nevada Pool (Table 2). Small amounts of excess milk were shipped to Inyo and Mono Counties in California. Milk production was localized in a few counties with irrigated farms. Pasture use in this area was generally quite limited. Many communities in Nevada were located in nonagricultural areas and were dependent upon bottled milk supplied from the milk 
producing areas. Milk supply areas and general milk distribution patterns are shown in Fig. 3.

Southern Nevada

Southern Nevada had a number of milk producing communities but also depended upon imported milk from southern Utah to satisfy the Las Vegas market (Table 3). Las Vegas was the primary distribution center for the region. Some milk bottled in Las Vegas was shipped to Needles, California, and also to northern Arizona. Lincoln County imported bottled milk and hay from southwestern Utah. Pasture utilization was relatively minor in southern Nevada. The general distribution pattern is illustrated in Fig. 4.

\section{Eastern Nevada}

The eastern part of Mevada had limited milk production from Lund and Lamoille, but was largely dependent upon Utah suppliers (Table 4). Most of the milk was supplied from Salt Lake City by Meadow Gold Dairy which in turn was supplied largely by farmers who were members of the Federated Producers Cooperative. The source of milk for this cooperative was complex (Tables 4,9 ). Very little pasture was used for local milk production in eastern Nevada, but pasture use by the contributors to Federated Producers was substantial. The milk distribution pattern for eastern Nevada is illustrated in Fig. 5 . Northern Arizona

Several communities in Coconino and Mohave Counties were included in Phase I. These were mostiy non-agricultural areas that were dependent upon milk shipped from Las Vegas or Phoenix (Table 5). Exceptions included the area around Fredonia and Littlefield, a dairy farming community on the Virgin River. The northern part of Coconino 


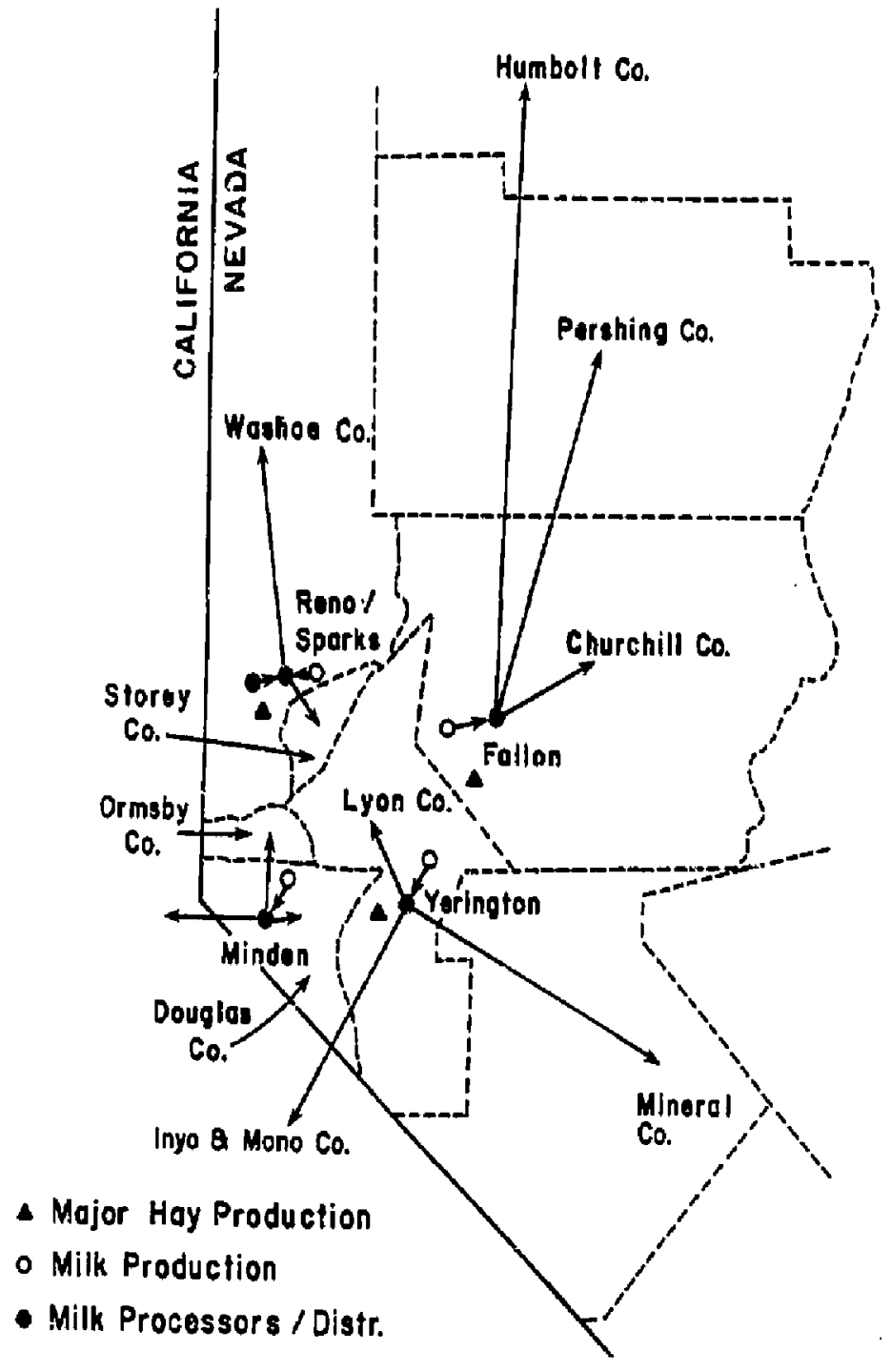

Fig. 3. Diagram of the major features of the milk network for western Nevada. 


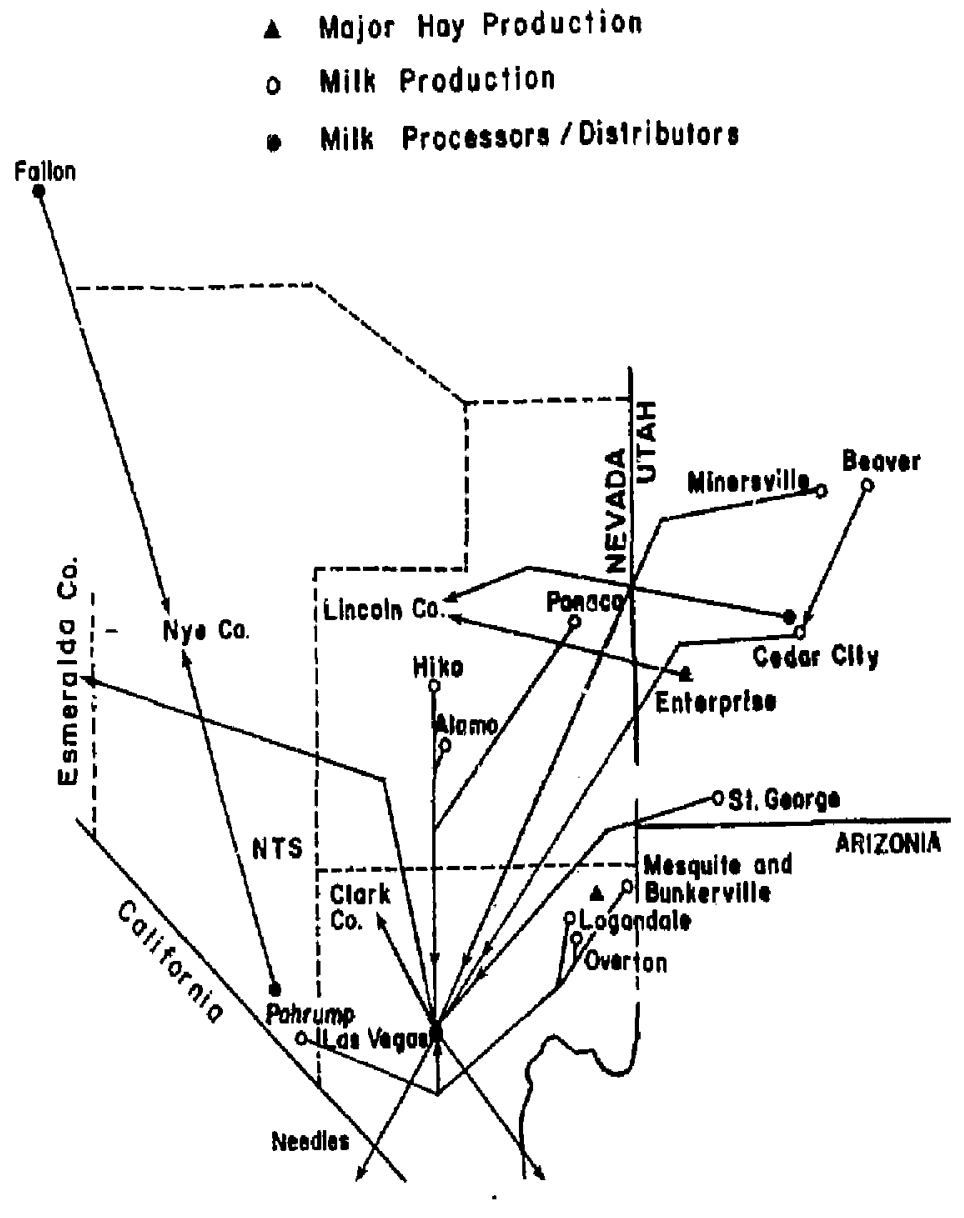

Fig. 4. Diagram of the major features of the milk network for southern Nevada. 


\section{- Milk Production}

- Milk Processors/Distributors

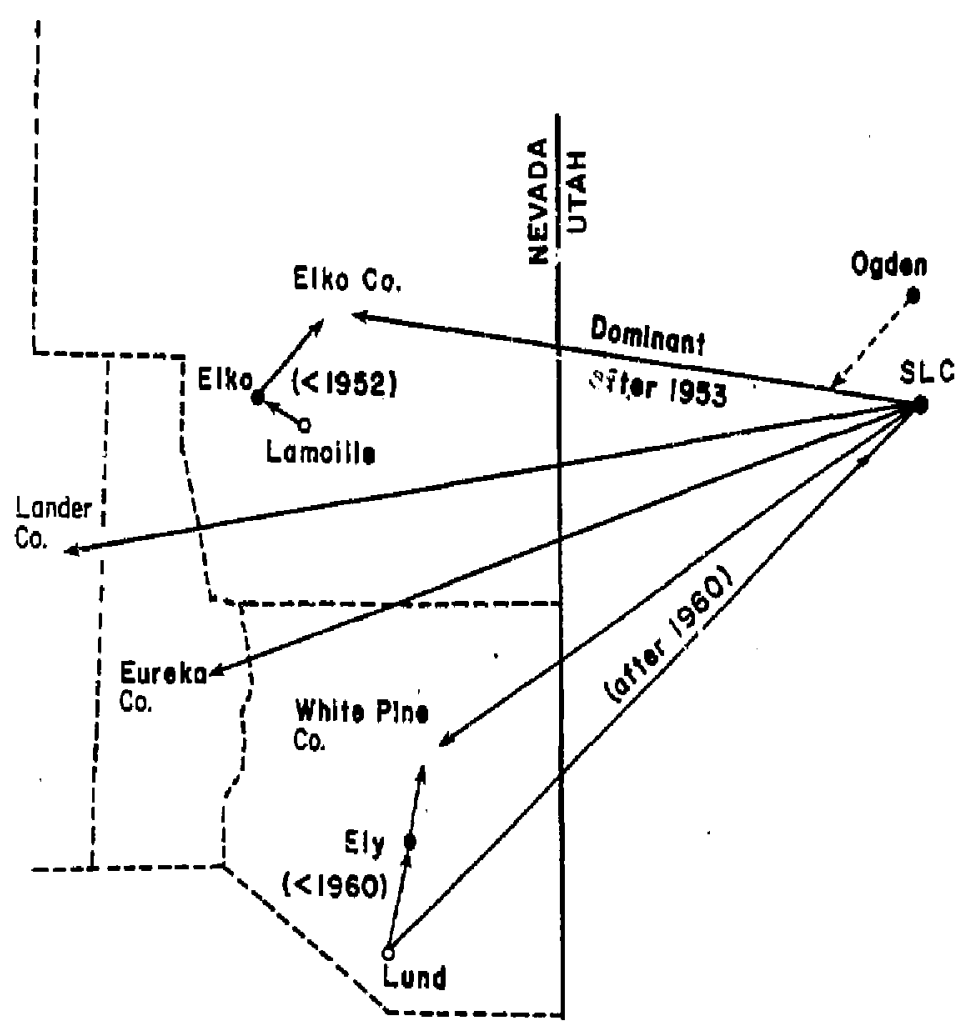

Fig. 5. Diagram of the major features of the milk network for eastern Nevada. 
County includes Flagstaff and cormunities north of the Colorado River (the "Arizona strip"). These cormunities (except Flagstaff) are similar to and closely associated with the neighboring communities in southern Utah. The only area of substantial pasture use was around Fredonia. Eastern California

Several communities located in Inyo, Kern, Mono, and eastern San Pernardino Counties were included in Phase 1. The more northern of these communities obtained some milk from western Nevada and some from local production (Table 6). The more southern cormunities in Kern and San Bernardino Counties are in desert areas with little or no agriculture. Milk was supplied to these communities primarily from the large dry-lot dairy farms in Los Angeles and western San Bernardino Counties.

\section{Phase II}

Data on milk distribution, feeding practices and delay time between grazing and consumption are presented for each state in the Phase II region by county and type of community (Tables 7 and 12-18).

\section{$\underline{\text { Utah }}$}

Utah includes the largest area in Phase II. It had the greatest milk production, the most complex distribution system, and some of its milk was exported to most neighboring states. The Utah data are surmarized in Table 7. Utah has 28 counties, nearly all of which were self-sufficient for local milk supplies. A large percentage of the total milk production in Utah in the 1950 s was not sold as fluid milk. 
but processed into cheese, butter, and dried milk. The amount of milk sold as fluid milk from the major producing counties in 1952 is illustrated in Fig. 6. Substantial amounts of bottled milk from Utah were shipped to neighboring states as indicated by estimates for 1952 and 1957 (Table 8).

During the period of interest, a number of small local dairy plants processed milk in Utah. However, bottled milk and other dairy products to a large extent were distributed from large dairy plants in the Salt Lake City area. Two of the major datry plants were operated by cooperatives; Hi-Land Dairy at Murray and Weber Central at Roy near Ogden. The Hi-Land and Heber Central Cooperatives collected milk from a number of counties (Table 9). Federated Producers was another large cooperative that during the period of interest did not process milk but marketed the milk of their producers to the private distributors and sonetimes to the other two cooperatives. Privately operated dairy plants supplied by Federated Producers were Safeway, Meadow Gold, Arden, and Cloverleaf. These plants distributed milk over a wide area.

The three cooperatives coilected milk primarily from the northern counties of Utah and provided most of the milk for the metropolitan area of the Salt Lake Basin. Some milk was also shipped from the dairy plants in the SaIt Lake City area to other parts of Utah as well as to eastern Nevada, and parts of northern Arizona, Colorado, and Wyoming. often, the milk from the three cooperatives was sold in the same markets. Consequent7y, the supply was considered to consist of one pool, referred to in TabTes 7 and $9-11$ as the "Utah Pool". In a few counties, milk from one of the cooperatives was the predominant source and this is so indicated in Table ?. 


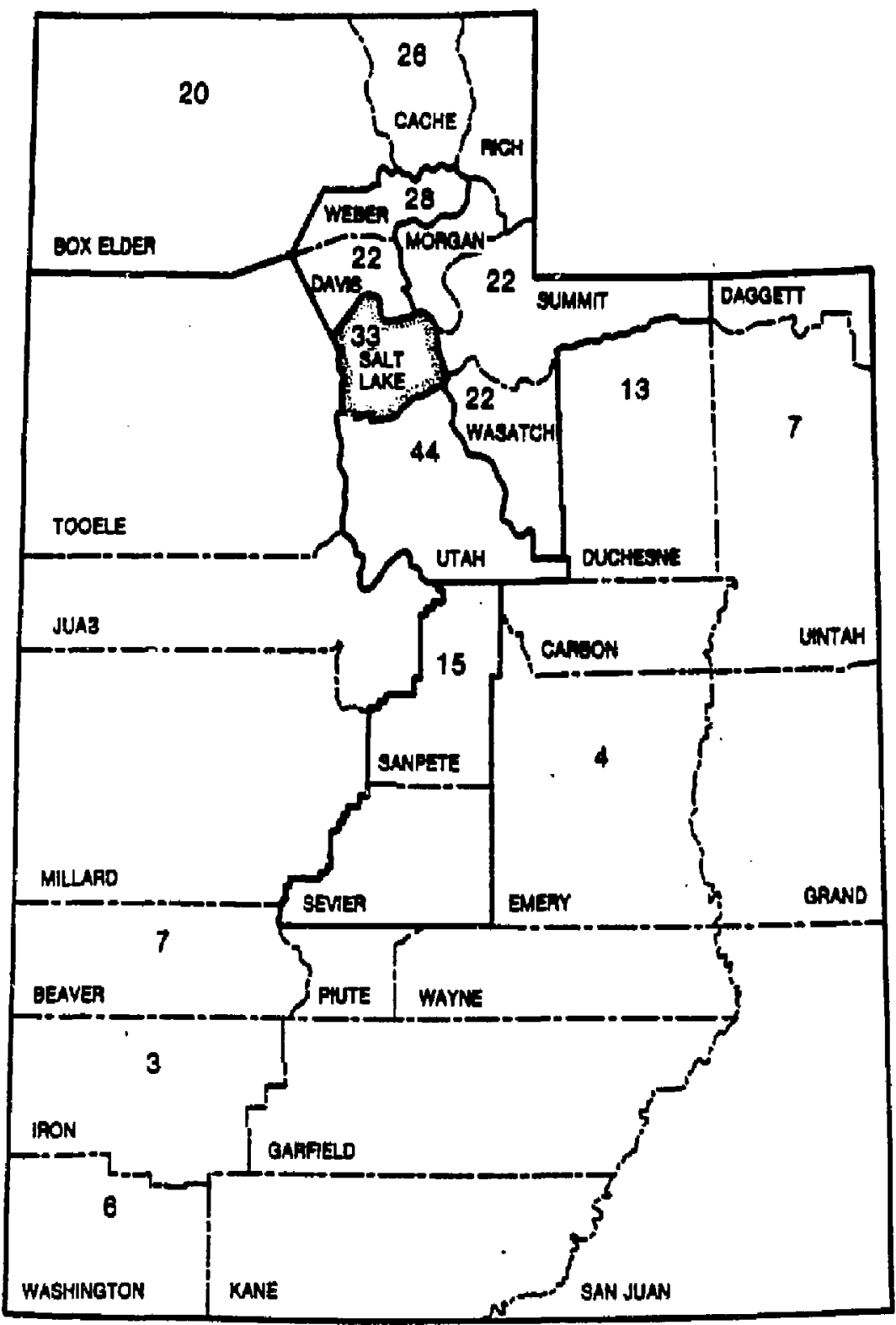

Fig. 6. Millions of pounds of Grade A milk sold in the major milkproducing counties in Utah, 1982. 
Federated Producers contributed about 50\% of the milk supply to the Ut.ah Pool while Hi-Land and Weber Central contributed about 25\% each. Table 9 indicates the percentage contribution of each county to each cocperative and to the Utah Pool. Tabie 10 summarizes the county contributions to the Utah Pool.

Feeding practices varied somewhat among counties but, in general, pasture use began May 15 and ende: September 15. The greatest variation was May 1 and October 1. Only small deviations from these limits occurred because of a limited supply of total feed for cows grazing early or late in the season. These deviations would have included only a small number of farms. The only exception is kashington County which has a langer pasture season. However, Washington County did not contribute significantly to the Utah Pool.

Estimates of feed intake from pasture varied considerably by counties, ranging from a low of $17 \%$ to a high of $80 \%$. A weighted average for cooperatives and the Utah Pool is presented in Table 11. The weighted Utah Pool average was $40 \%$ pasture.

\section{Arizona}

Data for Apache and Navajo Courties and the parts of Coconino County that were not covered in Phase I are summarized in Table 12. Much of the area consists of Indian reservations where sheep, goats and some beef cattle were grazed. Little or no milk was produced on the reservations and milk consumption was generally very low. A few irrigated farms produced some milk in Navajo and Apache counties. Milk supplies mostly came from the valley around Phoenix where large dairy herds were managed under confinement conditions and fed locally produced hay. Virtually no pasture was used in this area. 


\section{California}

Data are presented for the western part of San Bernardino County and Los Angeles County in Table 13. This area, one of the most populous in the country, is characterized by urban sprawl that has replaced much of the agriculture. Nevertheless, for many years the region has been self-sufficient in milk production through large-scale dry-lot dairy operations. Hay was supplied from the Antelope Yalley near Lancaster where irrigated alfalfa was the major agricultural crop. Essentially no pasture was ayailable in this area.

\section{Colorado}

Milk distribution and production information for the 12 Coloraco counties included in the Phase II area are sumarized in Table 14. These counties are located in the arid or mountainous regions of western Colorado and contain very little irrigated land suitable for dairy farming. An exception is the more populous area in and around Grand Junction (Mesa County) which had considerable farm land and significant dairy production. Mesa County contributed milk to most of the other counties in western Colorado. Delta County also helped to supply several other counties. The region was nearly self-sufficient in milk production aithough some milk was imported from Utah. Feeding practices in the 1950s were quite similar to those descrited for Utah. Pasture was an important feed source in this region except in Mesa County. 


\section{Idaho}

Data for the 16 Idaho counties included in the Phase II region are presented in Table 15. Nearly all of these small counties are clustered along the Snake River in southern Idaho. They were all important agricultural counties dependent upon irrigation, and milk production was a major enterprise. Because of a large production of milk, low population density, and no export market for fluid milk, the majority of the production was processed into cheese, butter and dried milk. Mearly all counties were self-sufficient for bottled milk because of the existence of many small dairy plants in the period of the 1950s. Cows were placed on irrigated pastures during the summer to a greater extent than in most othen areas of the west at that time, primarily because milk prices were relatively low and pasture was a cheap source of feed.

\section{Mew Mexico}

Data for the two northwestern counties of New Mexico included in the Phase II region, Mckinley and San Juan, are presented in Table 16. Mckinley County obtained mi $7 k$ from iocal dairy farms around Farmington, Durango, Colorado, and Albuquerque, New Mexico. The Albuquerque milk was largely supplied by local producers with dry-lot dairy operations. About one fourth of the Albuquerque milk supply was trucked in from southwestern Kansas. San Juan County received mi lk from both Albuquerque and Farmington. Modest use of pasture occurred in the Farmington area. 


\section{Oregon}

Data for Harney and Malheur Counties in the southeast corner of Oregon are presented in Table 17. Harney County was entirely grazing country with no farms or dairy herds. Like other ranching areas, some of the ranchers maintained their own milk cows while others purchased bottled milk in the nearest town. Malheur County borders the Snake River and the eastern edge of the county follows agricultural and dairy practices similar to the counties across the river in Idaho. This county produced milk for local consumption and export to Harney County. Pasture use in this area was significant.

\section{Hyoming}

Data for six Wyoming counties are presented in Table 18. Nearly all the area is very arid grazing land. The towns in the area depended heavily on mining, and many required milk imports. Only very limited areas of irrigated farming existed. The area around Riverton in Fremont County had some milk production which supplied that county and Hyoming towns to the: south. Dairy cows received little pasture in this valley. Milk from the Utah Pool was shipped into this area in increasing amounts over the period of interest. 


\section{SUMARY}

Information was compiled on the production and distribution of commercial milk supplies in nine western states during the 1950s. This information was essential for estimating the human ingestion of radionuclides such as ${ }^{131} \mathrm{I},{ }^{137} \mathrm{Cs}$ and ${ }^{90} \mathrm{Sr}$ through the pasture-to-mi $7 \mathrm{k}$ pathway. The information was used to estimate radiation doses to internal organs of peaple following deposition of radioactive fallout from atmospheric nuclear detonations conducted at the Nevada Test Site between 1951 and 1952 .

The data in the report represent the opinions of people involved in the dairy industry during the time period of interest. The approach of conducting personal interviews was necessary because little or no data were found in the titerature for the geographic area and time period of concern.

Milk production and distribution parameters varied substantially over both time and space. For example, pasture seasons ranged from 3 months in the coider regions to 6 months in the warmer climates. Pasture use ranged from near zero in the more arid regions to as much as 80\% of the total diet during the pasture season. Use of pastures generally declined through the 1950s and '60s. In general, pasture use was more prevalent in rural areas than near the more urban locales. Host residents of rural areas received milk from local suppliers. The main exceptions were areas without irrigation to grow pasture or hay. Residents in small towns generally had the option of purchasing dairy products from local dairies or from major regional distributors. 
The small, locally-owned dairies were quite prevalent in 1950, but by 1960 they had declined markedly in relative importance. The urban areas were primarily dependent on regional distributors. Large dairy cooperatives were located near Salt Lake City, Utah; Reno and Las Vegas, Nevada; Phoenix, Arizona; and Albuquerque, New Mexico (Fig. 7). These processor-distributors of ten received milk from rather widespread geographic areas.

Consumption of milk from private "back yard" cows was a very common practice in the early 1950s, especially in the more rural areas of Utah, Nevada and Idaho. With the exception of southern Utah and Nevada where a lifestyle survey of residents was conducted, we did not evaluate the importance of private milk sources. In terms of the general regional population, commercial milk was clearly dominant.

The shelf-life of commercial milk generally increased from 2 or 3 days to 4-6 days during the 1950 s because of better sanitation and bulk handling of milk. The longer milk storage times, the trend toward more dry hay feeding, and the pooling of milk from widespread geographic areas, all had the effect of reducing the human intake of radionuclides via milk consumption.

\section{ACXNONEDONENTS}

This work was sponsored by the U.S. Department of Energy, Nevada Operations Office, Las Vegas, Nevada 89114, through Contract DE-AS08$79 N 10057$ to Colorado State University and through Contract W-7405-ENG48 to Lawrence Livermore National Laboratory, Livermore, Ca]ifornia. He thank the individuals listed in Appendix 2 for providing the information 


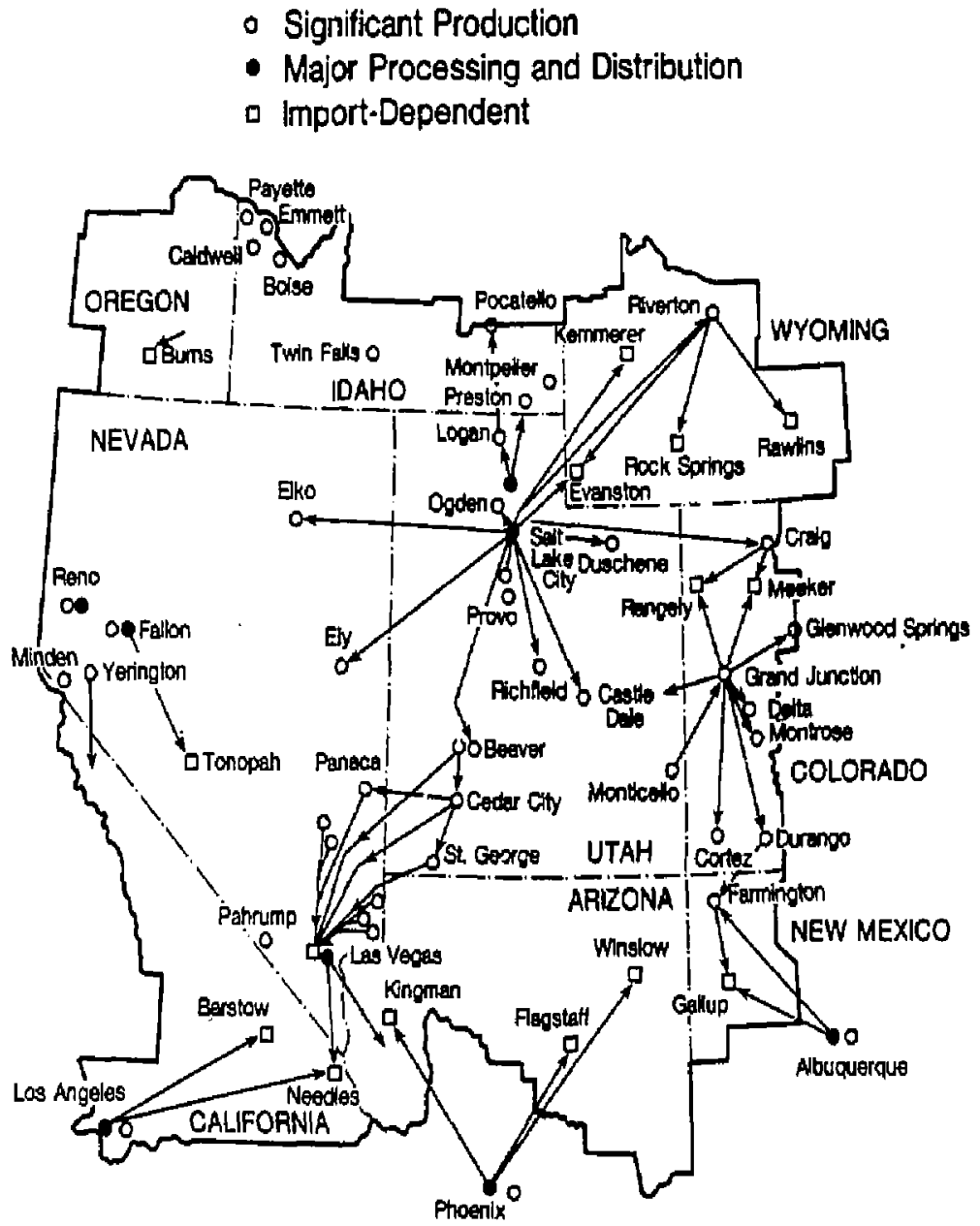

Fig. 7. Major features of the milk networks for the Phase I and Phase II areas of the Offsite Radiation Exposure Review Project, U.S. Department of Energy. 
essential to the preparation of this report. We also acknowledge the assistance of Howard Hawthorne, Don Gren, and Rebecca Crockett, University of Utah, for providing additional data concerning portions of Utah and Lincoin County, Nevada. 


\section{TABLES}


Table 1

Southwest Utah, Phase I

Mi I: Production and Distribution

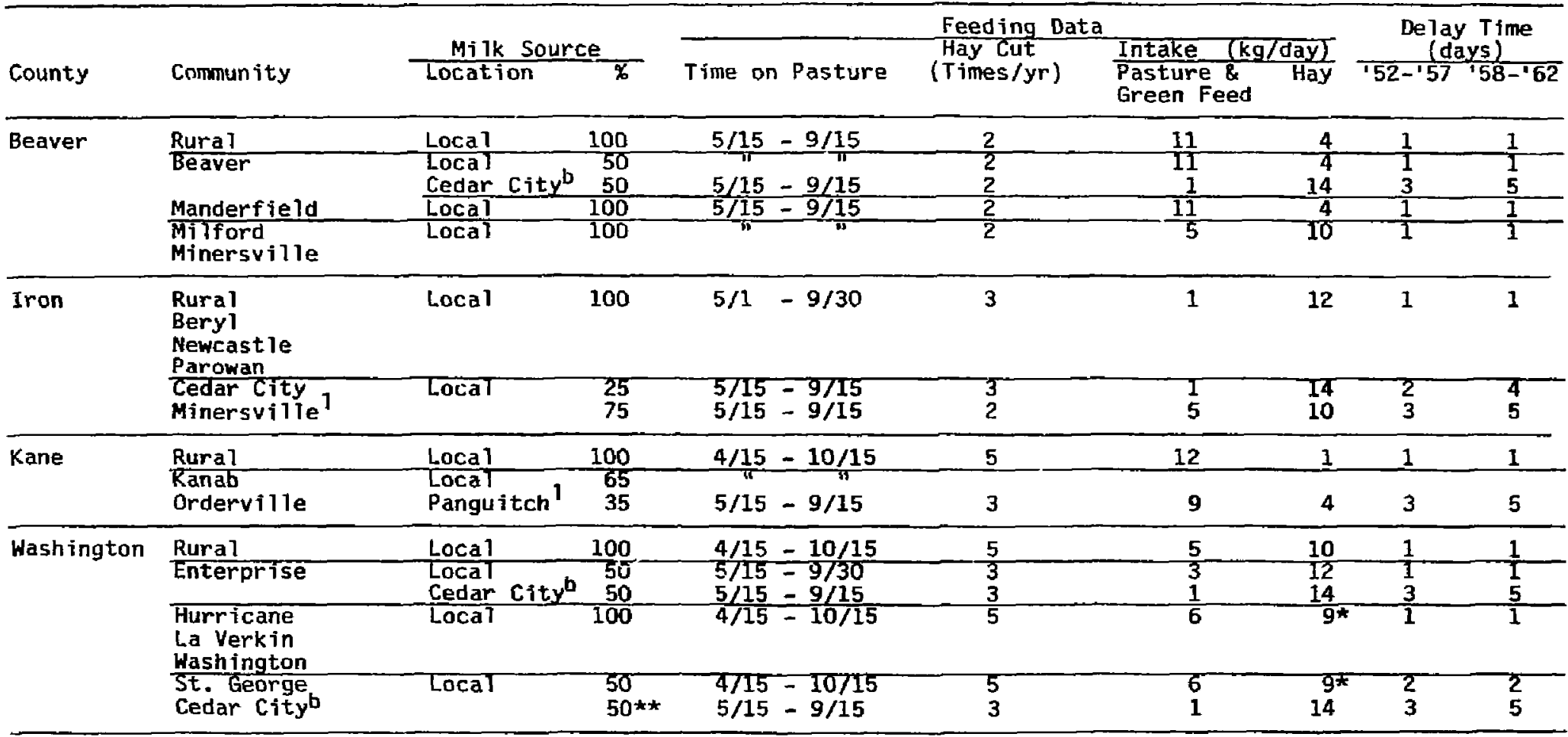

*30\% of hay produced at Enterprise, Utah. $1=10 \mathrm{cal}$ milk; b = bottled milk.

**After 1957, 25\% is from Cedar Cityb, and 25\% from Hi-Land Dairy (Table 9). 
Table 2

Western Nevada, Phase I

Milk Production and Distribution

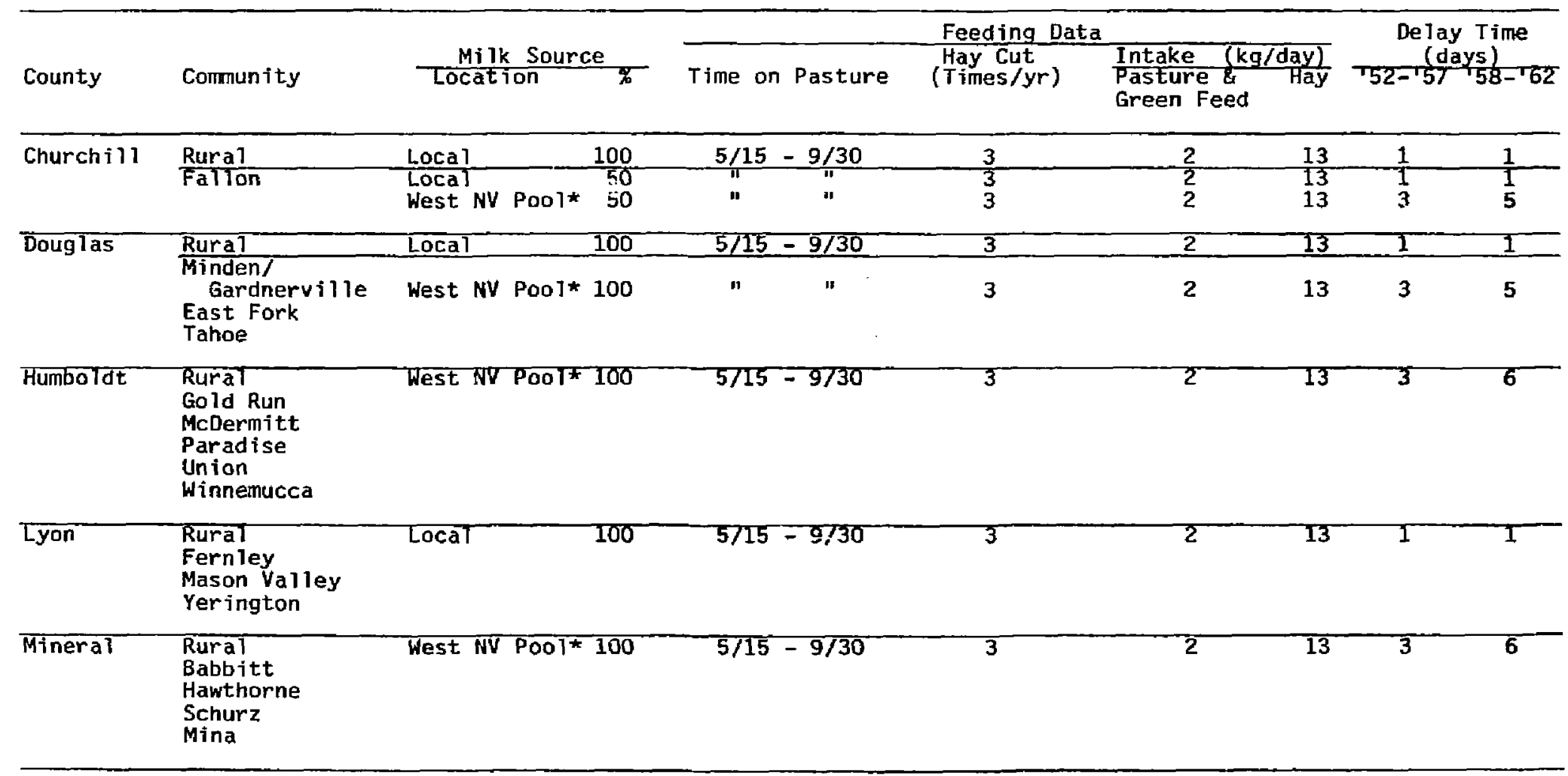


Table 2 (continued)

Western Nevada, Phase I

Milk Production and Distribution

\begin{tabular}{|c|c|c|c|c|c|c|}
\hline \multirow[b]{2}{*}{ County } & \multirow[b]{2}{*}{ Commun ity } & \multirow[b]{2}{*}{$\underset{\text { Milk Source }}{\text { Location }}$} & \multicolumn{3}{|c|}{ Feeding Data } & Delay Time \\
\hline & & & Time on Pasture & $\begin{array}{l}\text { Hay Cut } \\
\text { (Times/yr) }\end{array}$ & $\begin{array}{l}\text { Intake } \\
\text { Pasture } \\
\text { Green Feed }\end{array}$ & $\frac{\text { (days) }}{T 52-157 \text { 78-'62 }}$ \\
\hline
\end{tabular}

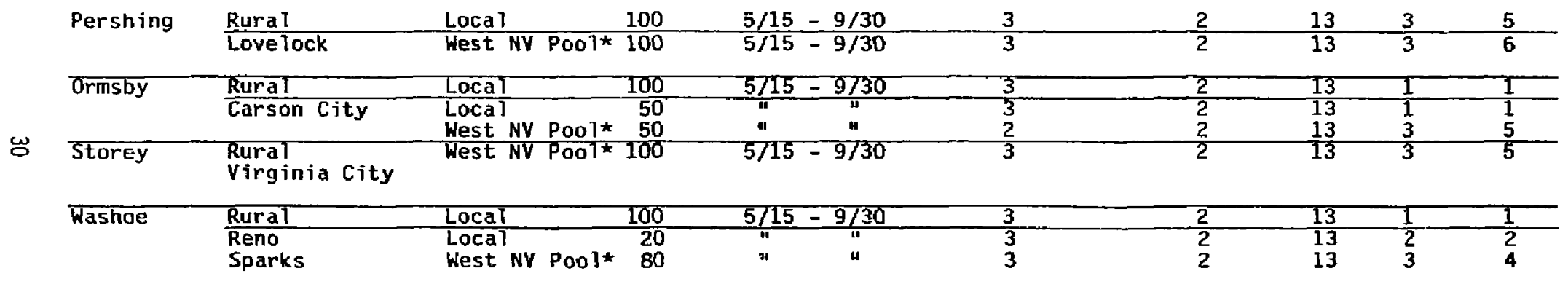

*West Nevada Pool consists of $50 \%$ Fallon-Fernly, 30z Reno, 12x Yerington, $8 \%$ Minden-Gardnerville. Each source provided local milk. 
Table 3

Southern Nevada, Phase I

Milk Production and Distribution

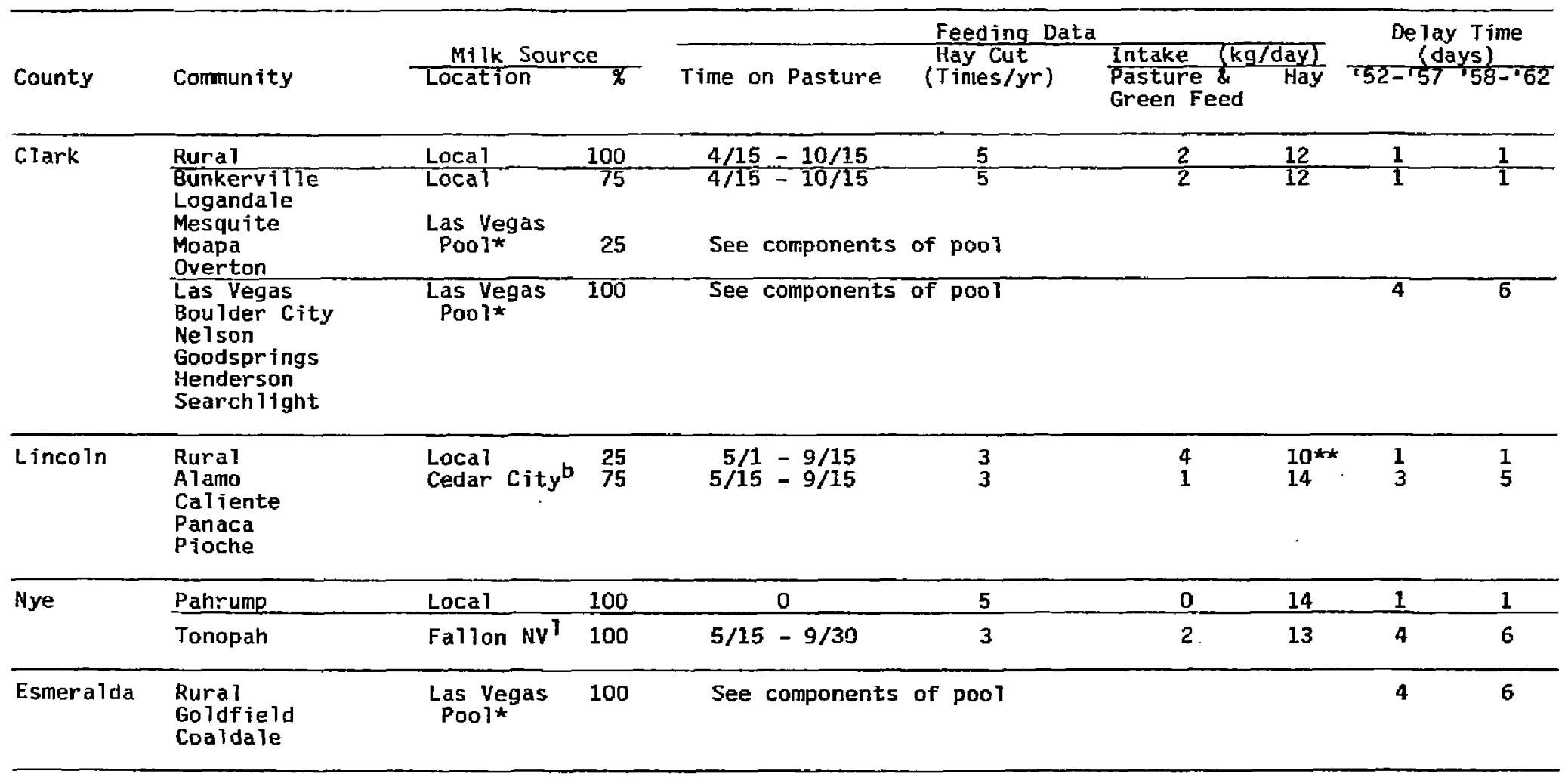

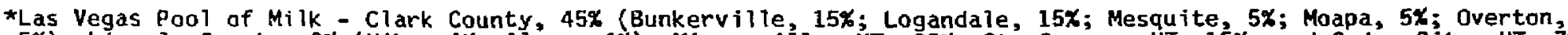

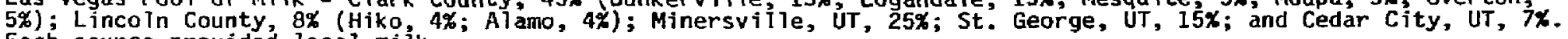
Each source provided locat mijk.

$\star \star 40 \%$ of hay produced at Enterprise, Washington County, UT.

$1=$ Tocal milk; $b=$ bott led milk. 
Table 4

Eastern Nevada, Phase I

Milk Production and Distribution

\begin{tabular}{|c|c|c|c|c|c|c|c|}
\hline \multirow[b]{2}{*}{ County } & \multirow[b]{2}{*}{ Community } & \multirow{2}{*}{\multicolumn{2}{|c|}{$\frac{\text { Mi Ik Source }}{\text { Location }}$}} & \multicolumn{3}{|c|}{ Feeding Data } & \multirow{2}{*}{$\begin{array}{c}\text { Delay Time } \\
\text { (days) } \\
\text { T52-T57 } 58-162\end{array}$} \\
\hline & & & & Time on Pasture & $\begin{array}{c}\text { Hay Cut } \\
\text { (Times/yr) }\end{array}$ & $\begin{array}{l}\text { Intake }(\mathrm{kg} / \mathrm{day}) \\
\text { Pasture \& } \\
\text { Green Feed }\end{array}$ & \\
\hline
\end{tabular}

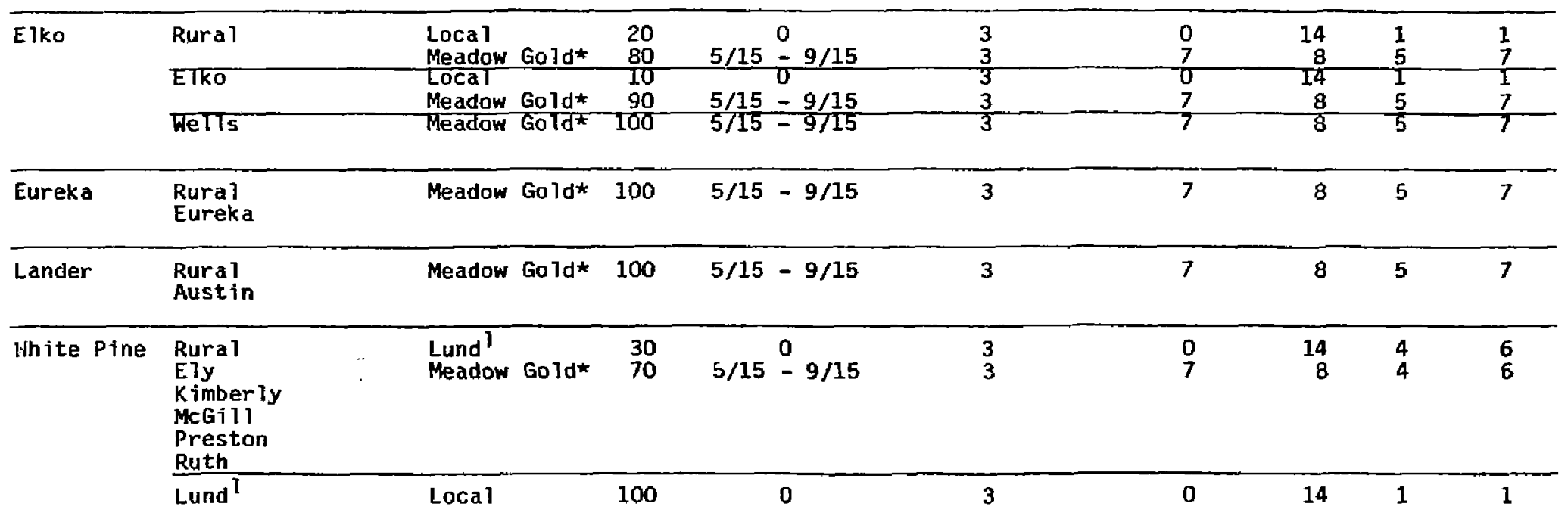

* Meadow Gold: Federated Producers of Salt Lake City supplied Meadow Gold Dairy, the principal mi]k supplier in eastern Nevada. Mi $7 k$ for Federated Producers was by county; $40 \%$ from Utah and $30 \%$ SaTt Lake; $8 \%$ from Weber and $7 \%$ Davis; $5 \%$ from Cache and $5 \%$ Box Elder; and $3 \%$ from Wasatch and $2 \%$ Duschene. Each source area provided $10 c a l$ milk. See Walters et a1. (1985) for feeding practices in these counties. $1=$ locaj milk 
Table 5

Northern Arizona, Phase I

Milk Production and Distribution

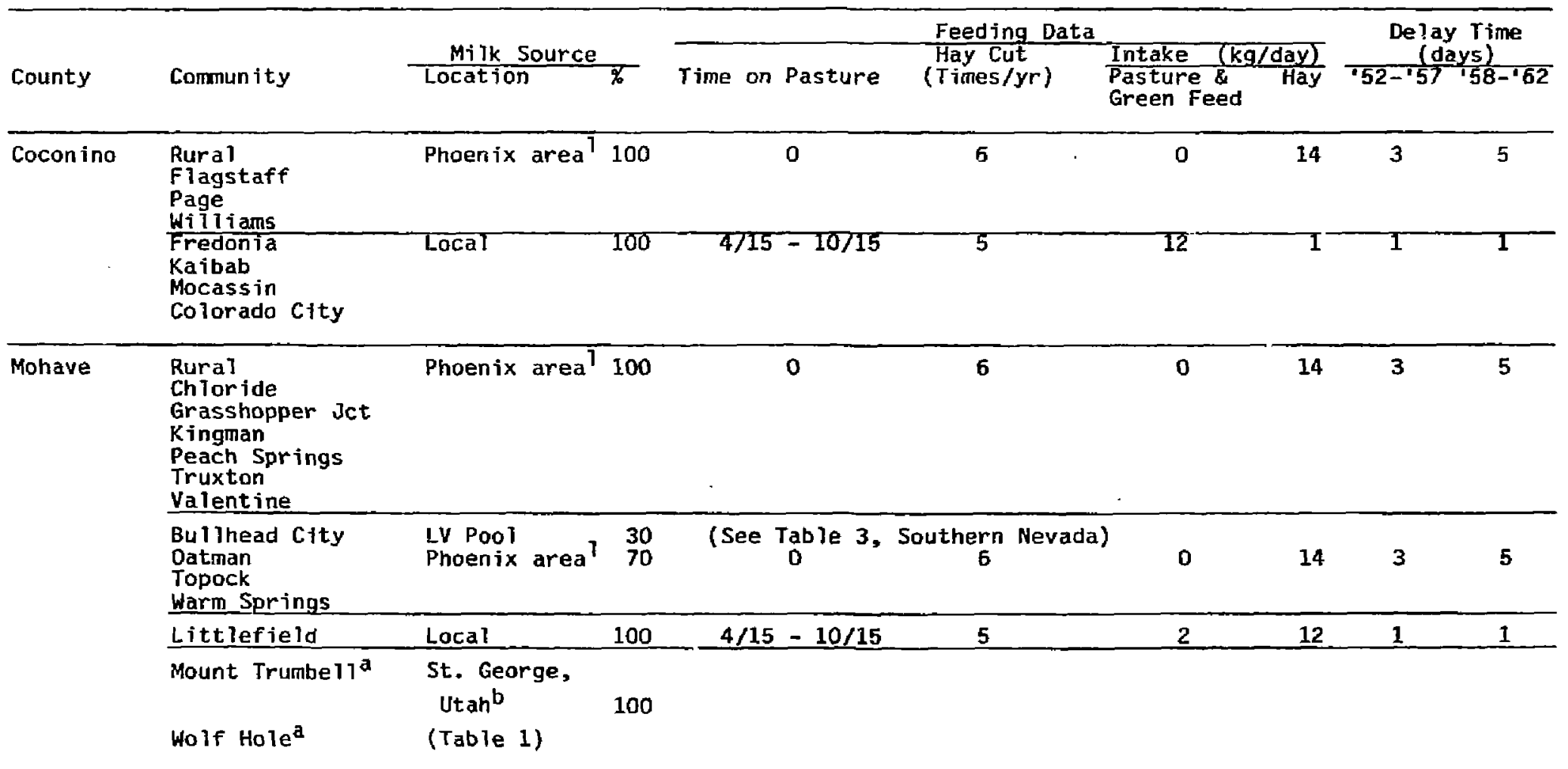

a No permanent population

$1=$ loca $1 \mathrm{mi} 7 \mathrm{k}$; b=bottled milk 
Table 6

Eastern California, Phase I

Milk Production and Distribution

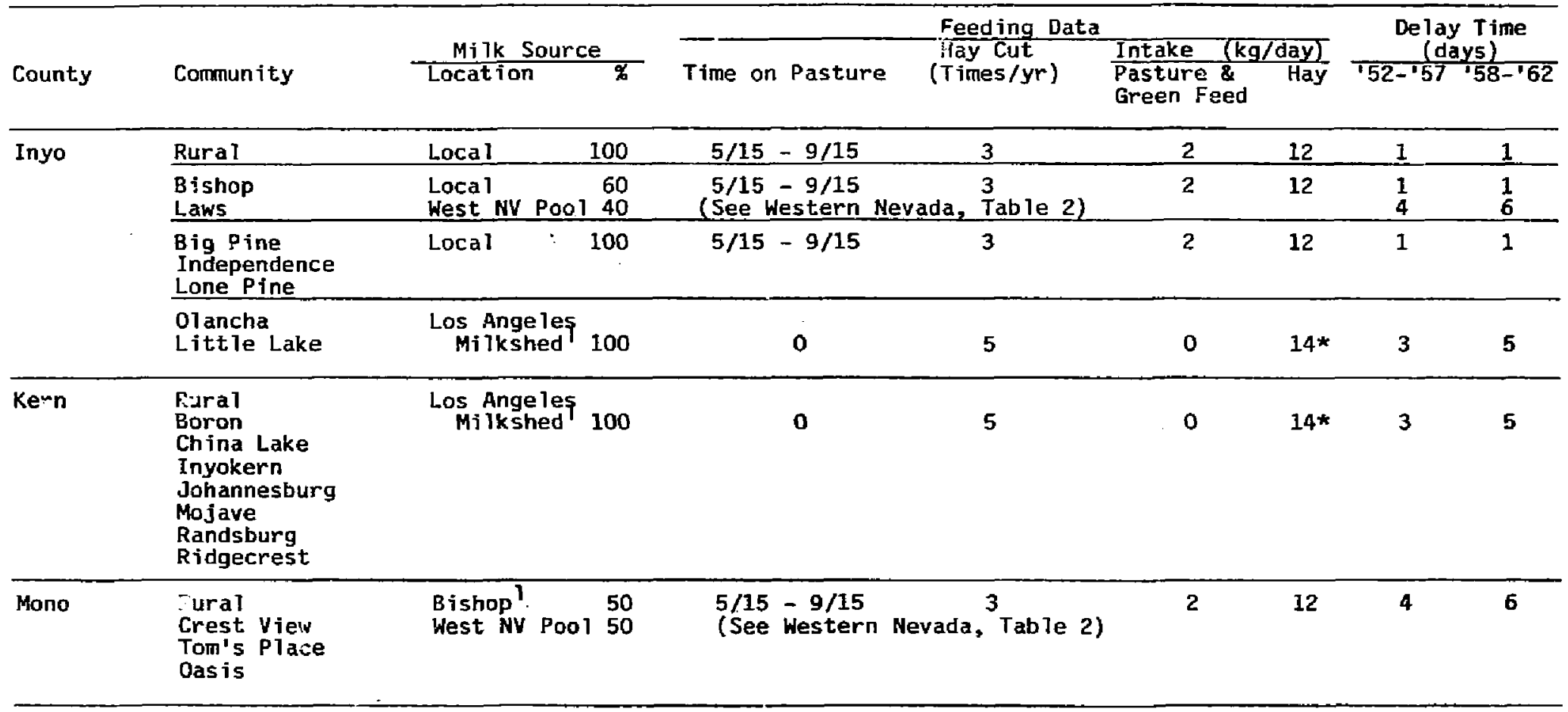

l=local milk 
Table 6 (continued)

Eastern California, Phase I

Milk Production and Distribution

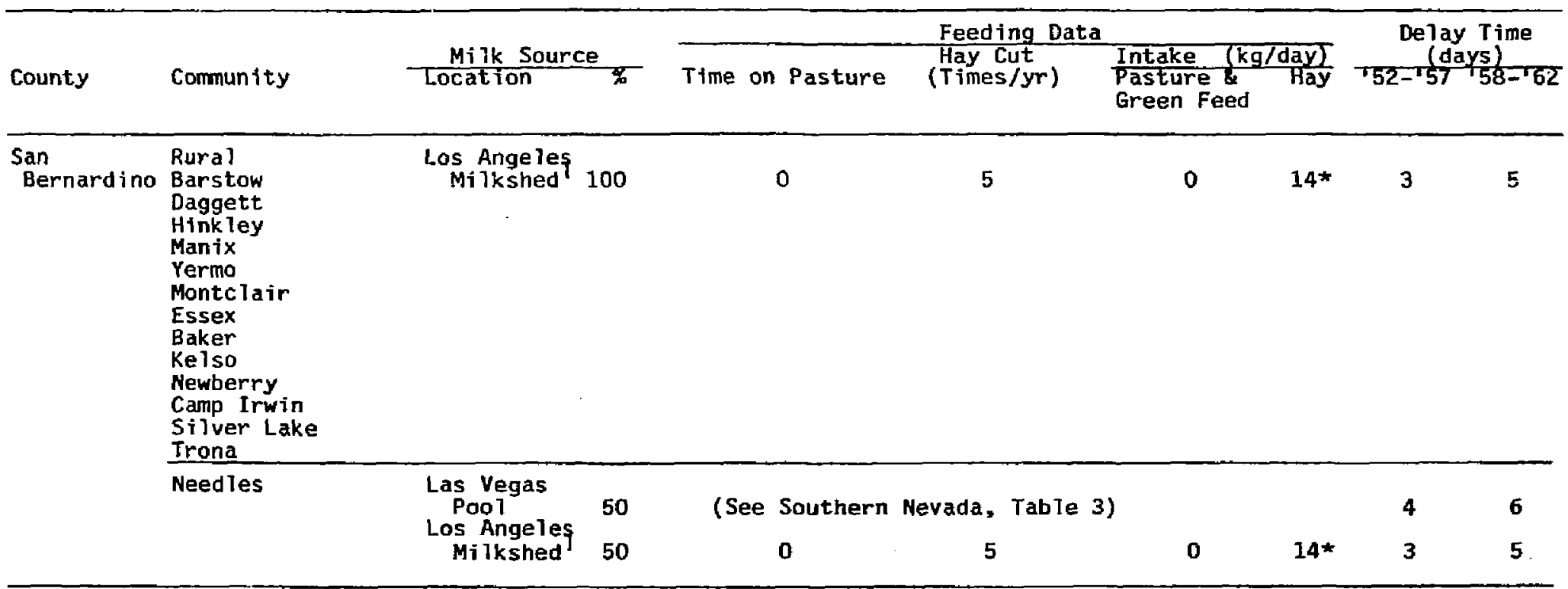

* Hay from Lancastar, CA.

$1=$ local milk 
Table 7

Utah. Phase II

Milk Production and Distribution

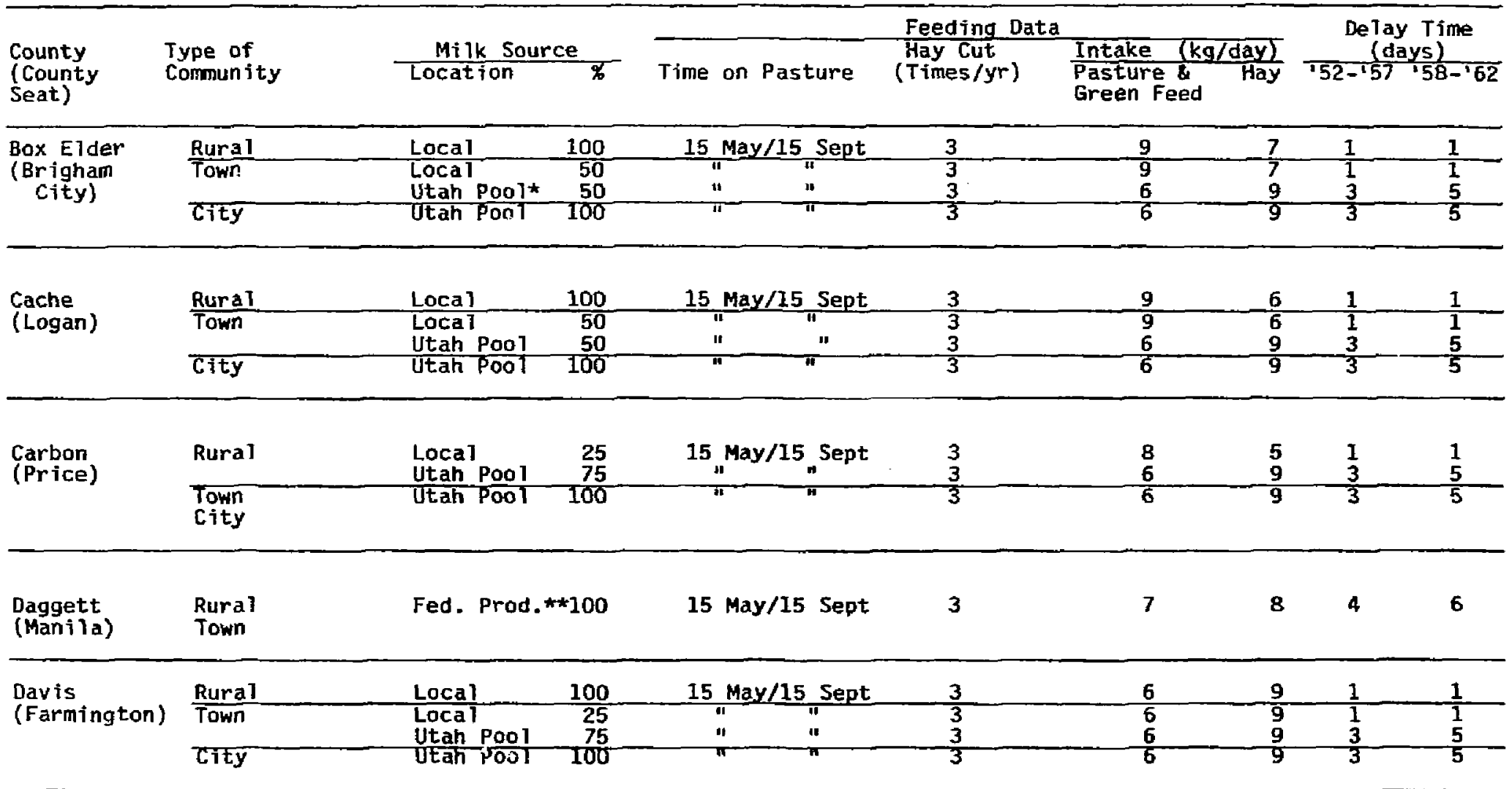


Table 7 (continued)

Utah, Phase II

Milk Production and Distribution

\begin{tabular}{|c|c|c|c|c|c|c|}
\hline & & & & Feeding Data & & De]ay Time \\
\hline $\begin{array}{l}\text { County } \\
\text { (County } \\
\text { Seat) }\end{array}$ & $\begin{array}{l}\text { Type of } \\
\text { Community }\end{array}$ & $\frac{\text { Mllk Source }}{\text { Location }}$ & Time on Pasture & $\begin{array}{l}\text { Hay Cut } \\
\text { (Times /yr) }\end{array}$ & $\begin{array}{l}\text { Intake }(\mathrm{kg} / \text { day }) \\
\text { Pasture to Hay } \\
\text { Green Feed }\end{array}$ & $\frac{\text { (days) }}{52-57 \cdot 58-162}$ \\
\hline
\end{tabular}

\begin{tabular}{|c|c|c|c|c|c|c|c|c|c|}
\hline $\begin{array}{l}\text { Duschene } \\
\text { (Duschene) }\end{array}$ & $\frac{\text { Rural }}{\text { Town }}$ & $\frac{\text { Local }}{\text { Loca1 } 1}$ & $\begin{array}{r}100 \\
50 \\
50\end{array}$ & $\frac{1 \text { June/30 Rug }}{15 \text { May } / 15 \text { Sept }}$ & $\begin{array}{l}2 \\
2 \\
3\end{array}$ & $\begin{array}{l}9 \\
9 \\
6\end{array}$ & $\begin{array}{l}5 \\
6 \\
9\end{array}$ & $\frac{1}{\frac{1}{3}}$ & 5 \\
\hline
\end{tabular}

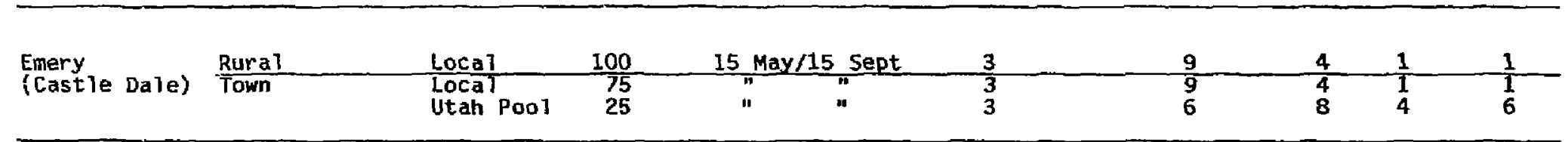

\begin{tabular}{|c|c|c|c|c|c|c|c|c|c|}
\hline $\begin{array}{l}\text { Garfield } \\
\text { (Panguitch) }\end{array}$ & $\frac{\text { Rural }}{\text { Town }}$ & $\begin{array}{l}\text { Local } \\
\text { Local } \\
\text { Utah Pool }\end{array}$ & $\begin{array}{r}100 \\
50 \\
50\end{array}$ & $\frac{15 \text { May } / 15 \text { Sept }}{n}$ & $\begin{array}{l}\mathbf{3} \\
\mathbf{3} \\
\mathbf{3}\end{array}$ & $\begin{array}{l}9 \\
9 \\
6\end{array}$ & $\begin{array}{l}4 \\
4 \\
8\end{array}$ & $\frac{1}{1}$ & $\begin{array}{l}1 \\
1 \\
5\end{array}$ \\
\hline $\begin{array}{l}\text { Grand } \\
\text { (Moab) }\end{array}$ & Rural & $\begin{array}{l}\text { Fed. Prod. } \\
\text { Grand Junc- } \\
\text { tion, co }\end{array}$ & $\begin{array}{l}75 \\
25\end{array}$ & $\begin{array}{c}15 \text { May/15 Sept } \\
\text { " }\end{array}$ & $\begin{array}{l}3 \\
4\end{array}$ & $\begin{array}{l}7 \\
2\end{array}$ & $\begin{array}{r}8 \\
13\end{array}$ & $\begin{array}{l}4 \\
4\end{array}$ & 6 \\
\hline $\begin{array}{l}\text { Juab } \\
\text { (Nephi) }\end{array}$ & $\frac{\text { Rural }}{\text { Town }}$ & $\frac{\text { Loca }]}{\text { Loca1 }}$ & $\begin{array}{r}100 \\
50 \\
50\end{array}$ & $\frac{25 \operatorname{May} / 15 \operatorname{Sept}}{" 1}$ & $\begin{array}{l}3 \\
3 \\
3\end{array}$ & $\begin{array}{l}8 \\
8 \\
6\end{array}$ & $\begin{array}{l}7 \\
7 \\
8\end{array}$ & $\frac{1}{\frac{1}{3}}$ & $\frac{1}{1}$ \\
\hline $\begin{array}{l}\text { Mi } 1 \text { lard } \\
\text { (Fillmore) }\end{array}$ & $\begin{array}{l}\text { Rura } 1 \\
\text { Town }\end{array}$ & $\begin{array}{l}\text { Local } \\
\text { Utah Pool } \\
\text { Local Pool }\end{array}$ & $\begin{array}{l}75 \\
25 \\
-50 \\
50\end{array}$ & $\underbrace{15 \text { May/15 Sept }}_{\|}$ & $\begin{array}{l}3 \\
3 \\
3 \\
3\end{array}$ & $\begin{array}{l}8 \\
6 \\
8 \\
6\end{array}$ & $\begin{array}{l}7 \\
8 \\
7 \\
8\end{array}$ & $\begin{array}{l}1 \\
4 \\
1\end{array}$ & $\begin{array}{l}1 \\
6 \\
1 \\
5\end{array}$ \\
\hline
\end{tabular}


Table 7 (continued)

Utah, Phase II

Milk Production and Distribution

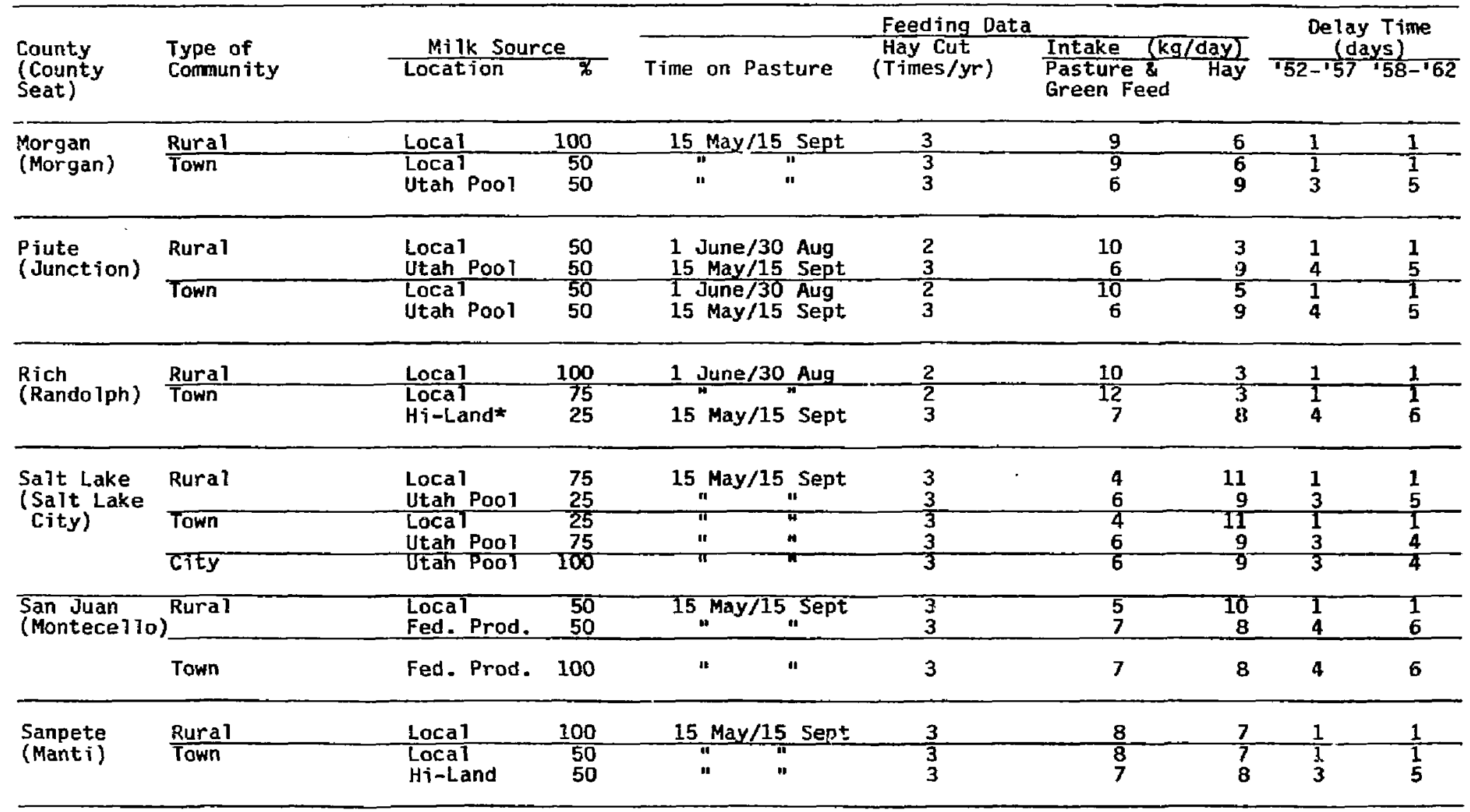


Table 7 (continued)

Utah, Phase II

Milk Production and Distribution

\begin{tabular}{|c|c|c|c|c|c|c|}
\hline \multirow{3}{*}{$\begin{array}{l}\text { County } \\
\text { (County } \\
\text { Seat) }\end{array}$} & \multirow{3}{*}{$\begin{array}{l}\text { Type of } \\
\text { Community }\end{array}$} & \multirow[b]{2}{*}{ Milk Source } & \multicolumn{3}{|c|}{ Feeding Data } & \multirow{3}{*}{$\begin{array}{c}\text { Delay Time } \\
\text { (days) } \\
52-{ }^{-57}{ }^{\prime} 58-{ }^{1} 62\end{array}$} \\
\hline & & & & Hay Cut & $(\mathrm{kg} / \mathrm{day})$ & \\
\hline & & Location $\%$ & Time on Pasture & (Times/yr) & $\begin{array}{l}\text { Pasture \& } \\
\text { Green Feed }\end{array}$ & \\
\hline
\end{tabular}

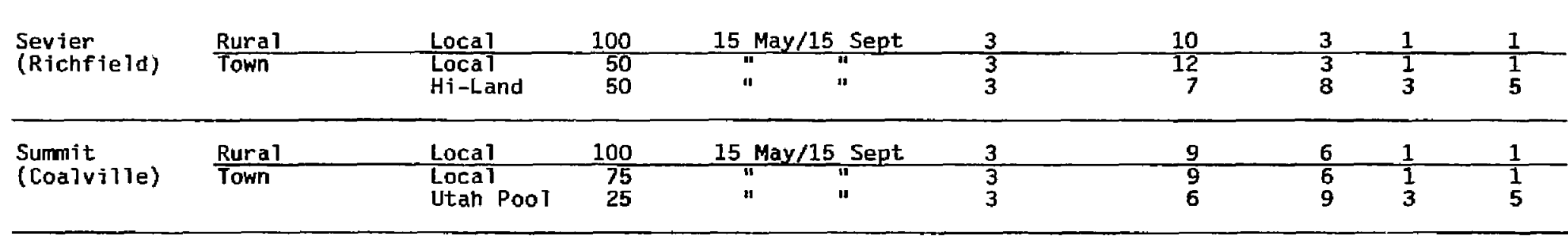

\begin{tabular}{|c|c|c|c|c|c|c|c|c|c|}
\hline $\begin{array}{l}\text { Tooele } \\
\text { (Tooele) }\end{array}$ & $\begin{array}{l}\text { Rural } \\
\text { Town }\end{array}$ & $\begin{array}{l}\text { Local } \\
\text { Utah Pool } \\
\text { Utah Pool }\end{array}$ & $\begin{array}{r}50 \\
50 \\
100\end{array}$ & 15 May/15 Sept & $\begin{array}{l}3 \\
3 \\
3\end{array}$ & $\begin{array}{r}7 \\
5 \\
-6\end{array}$ & $\begin{array}{l}6 \\
9 \\
9\end{array}$ & $\begin{array}{l}1 \\
3 \\
3\end{array}$ & $\begin{array}{l}1 \\
5 \\
5\end{array}$ \\
\hline $\begin{array}{l}\text { Uintah } \\
\text { (Vernal) }\end{array}$ & $\frac{\text { Rura } 1}{\text { Town }}$ & $\begin{array}{l}\text { Loca } 1 \\
\text { Loca1 } \\
\text { Hi-Land }\end{array}$ & $\begin{array}{r}100 \\
75 \\
25\end{array}$ & $\frac{1 \text { June/30 Aug }}{15 \text { May/ } 15 \text { Sept }}$ & $\begin{array}{l}2 \\
2 \\
3\end{array}$ & $\begin{array}{r}9 \\
-\frac{9}{7}\end{array}$ & $\begin{array}{l}5 \\
6 \\
8\end{array}$ & $\begin{array}{l}1 \\
\frac{1}{3}\end{array}$ & $\begin{array}{l}1 \\
1 \\
5\end{array}$ \\
\hline $\begin{array}{l}\text { Utah } \\
\text { (Provo) }\end{array}$ & $\begin{array}{l}\text { Rural } \\
\text { Town } \\
\text { City }\end{array}$ & $\begin{array}{l}\text { Local } \\
\text { Utah Pool } \\
\text { Loca } 1 \\
\text { Utah Pool } \\
\text { Utah Poot }\end{array}$ & $\begin{array}{r}75 \\
25 \\
25 \\
75 \\
100\end{array}$ & 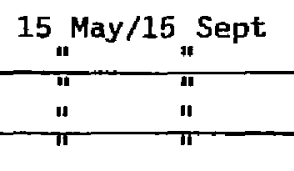 & $\begin{array}{l}3 \\
3 \\
3 \\
3 \\
3\end{array}$ & $\begin{array}{l}7 \\
6 \\
7 \\
6 \\
6\end{array}$ & $\begin{array}{l}8 \\
9 \\
8 \\
9 \\
9\end{array}$ & $\begin{array}{l}1 \\
\frac{1}{1} \\
\frac{3}{3} \\
3\end{array}$ & $\begin{array}{l}1 \\
5 \\
1 \\
5 \\
5\end{array}$ \\
\hline $\begin{array}{l}\text { Wasatch } \\
\text { (Heber } \\
\text { City) }\end{array}$ & $\frac{\text { RuraI }}{\text { Town }}$ & $\frac{\text { Local }}{\text { Loca1 }}$ & $\begin{array}{r}100 \\
50 \\
50\end{array}$ & $\frac{15 \text { May } / 15 \text { Sept }}{" 1 "}$ & $\begin{array}{r}3 \\
3 \\
3\end{array}$ & $\begin{array}{r}9 \\
-9 \\
6\end{array}$ & $\begin{array}{l}\frac{E}{6} \\
\frac{9}{9}\end{array}$ & $\frac{1}{1}$ & $\frac{1}{1}$ \\
\hline
\end{tabular}


Table 7 (continued)

Utah, Phase II

Milk Production and Distributior.

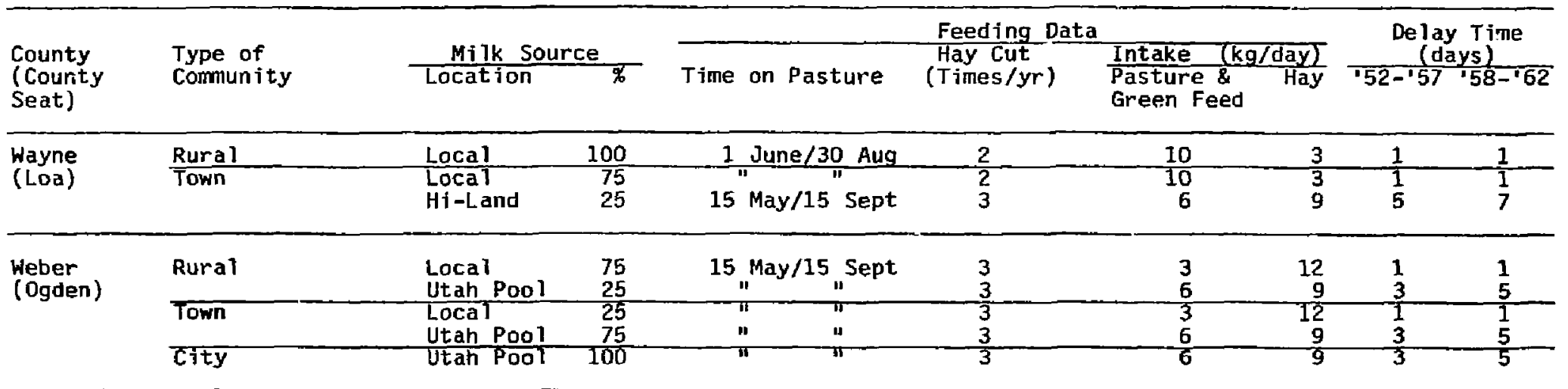

* Utah Pool - Refers to a pool of three cooperatives; the contribution of each and the counties supplying are described in Tables 9, 10. Each source suppties local milk.

* Fed. Prod. - Federated Producers, one of three cooperatives (Table 9).

*** Hi-Land - One of three cooperatives (Table 9). 
Table 8. Out-of-state sales of fluid mi!! from Utah in 1952 and 1957 (mitk equivalent, 000 's lbs.)

\begin{tabular}{lcc}
\hline Sales to: & 1952 & 1957 \\
\hline Arizona & $\cdots$ & 357 \\
Colorado & $\ldots \ldots$ & $549 *$ \\
Nevada & 13,254 & 26,986 \\
Idaho & $\cdots$ & 2,876 \\
Wyoming & 12,049 & 11,087 \\
\hline
\end{tabular}

*Shipments to Denver, Colorado, in 1959 were 10 million lbs., mostly from Logan, Utah. Source: Christiansen, R. 1959, Utah State University, Logan, Utah. 
Table 9. County contributions to the milk supply of the three major cooperatives in $\mathrm{Ut}$ tah, and contributions of the cooperatives to the Utah Pool.

\begin{tabular}{|c|c|c|c|c|}
\hline \multirow[b]{2}{*}{ Cooperative } & \multicolumn{2}{|c|}{ Suppliers ${ }^{*}$} & \multirow{2}{*}{$\begin{array}{l}\text { Cooperative's } \\
\text { Contribution } \\
\text { to Utah Pool }(\%)\end{array}$} & \multirow{2}{*}{$\begin{array}{l}\text { County } \\
\text { Contributions } \\
\text { to Utah Pool }(\gamma)\end{array}$} \\
\hline & County & 7 & & \\
\hline $\begin{array}{l}\text { Federated } \\
\text { Producers }\end{array}$ & $\begin{array}{l}\text { Utah } \\
\text { Sait Lake } \\
\text { Weber } \\
\text { Davis } \\
\text { Cache } \\
\text { Box Elder } \\
\text { Duchesne } \\
\text { Wasatch }\end{array}$ & $\begin{array}{r}40 \\
30 \\
8 \\
7 \\
5 \\
5 \\
2 \\
3\end{array}$ & 50 & $\begin{array}{l}20 \\
15 \\
4 \\
3.5 \\
2.5 \\
2.5 \\
1 \\
1.5\end{array}$ \\
\hline $\begin{array}{c}\text { Hi-Land Dairy } \\
\text { Producers }\end{array}$ & $\begin{array}{l}\text { Utah } \\
\text { Salt Lake } \\
\text { Summit } \\
\text { Ouchesne } \\
\text { Uintah } \\
\text { Sanpete } \\
\text { Beaver } \\
\text { Emery } \\
\text { Nevada } \\
\text { (Lincoln and }\end{array}$ & $\begin{array}{r}30 \\
20 \\
20 \\
10 \\
10 \\
2 \\
5 \\
2 \\
1 \\
\text { hite }\end{array}$ & $\begin{array}{l}25 \\
\text { Pine Counties) }\end{array}$ & $\begin{array}{l}7.5 \\
5 \\
5 \\
2.5 \\
2.5 \\
0.5 \\
1.3 \\
0.5 \\
0.2\end{array}$ \\
\hline $\begin{array}{l}\text { Weber Central } \\
\text { Dairy }\end{array}$ & $\begin{array}{l}\text { Weber } \\
\text { Davis } \\
\text { Salt Lake } \\
\text { Morgan } \\
\text { Box Elder } \\
\text { Cache } \\
\text { Fremont (WY) }\end{array}$ & $\begin{array}{r}30 \\
20 \\
15 \\
15 \\
10 \\
9 \\
1\end{array}$ & 25 & $\begin{array}{l}7.5 \\
5 \\
3.8 \\
3.8 \\
2.5 \\
2.2 \\
0.2\end{array}$ \\
\hline
\end{tabular}

* Each source supplied local milk. 
Tabie 10. County contributions to the Utah milk poor.

\begin{tabular}{lcccc}
\hline & \multicolumn{4}{c}{ * Contribution } \\
\cline { 2 - 6 } County $^{*}$ & $\begin{array}{c}\text { Federated } \\
\text { Producers }\end{array}$ & $\begin{array}{c}\text { Hi-Land } \\
\text { Dairy }\end{array}$ & $\begin{array}{c}\text { Weber } \\
\text { Central }\end{array}$ & $\begin{array}{c}\text { County } \\
\text { Total }\end{array}$ \\
\hline Utah & 20 & 7.5 & & 27.5 \\
Salt Lake & 15 & 5 & 3.8 & 23.8 \\
Weber & 4 & & 7.5 & 11.5 \\
Davis & 3.5 & & 5 & 8.5 \\
Cache & 2.5 & & 2.2 & 4.7 \\
Box Elder & 2.5 & & 2.5 & 5.0 \\
Duchesne & 1 & 2.5 & & 3.5 \\
Wasatch & 1.5 & & & 1.5 \\
Summit & & 5 & & 5.0 \\
Uintah & & 2.5 & & 2.5 \\
Sanpete & & 0.5 & & 0.5 \\
Beaver & & 1.3 & & 1.3 \\
Emery & & 0.5 & & 0.5 \\
White Pine, Lincoln (NY) & & 0.2 & & 0.2 \\
Morgan & & & 3.8 & 3.8 \\
Fremont (WY) & & & 0.2 & 0.2 \\
\hline
\end{tabular}

* Each source county supplied local milk. 
Table 11. Average pasture and hay intake for cows producing milk for the Utah Pool.

\begin{tabular}{lll}
\hline Milk Source & \multicolumn{2}{c}{ Feed Ory Matter Intake (kg/day) } \\
\cline { 3 - 3 } Pasture & \\
\hline & & 9.6 \\
Weber Central Dairy & 5.4 & 8.0 \\
Hi-Land Dairy & 7.0 & 8.4 \\
Federated Producers & 6.6 & 9 \\
Utah Pool & 6 & \\
\hline
\end{tabular}


Table 12

Arizona, Phase II

Milk Production and Distribution

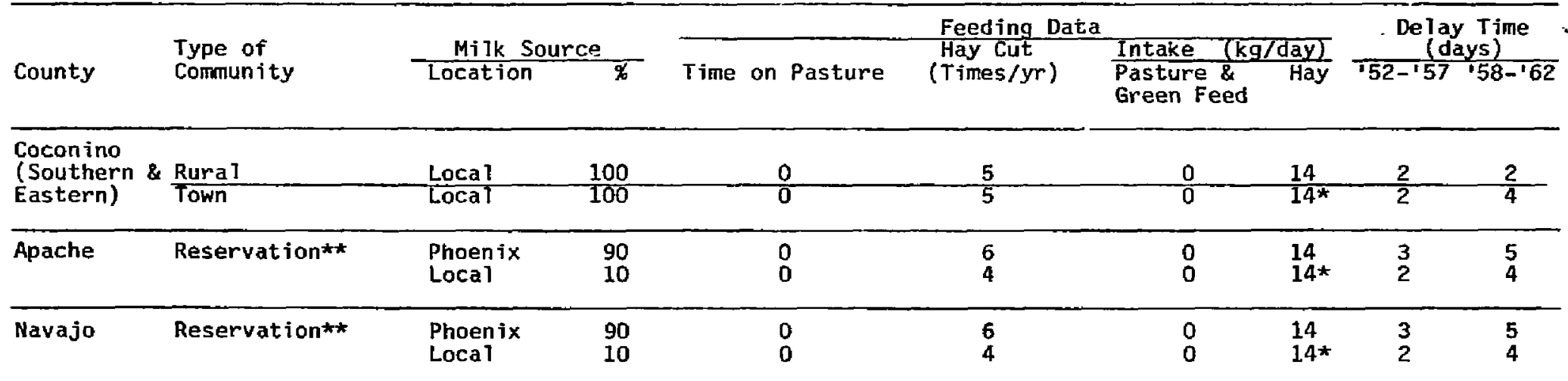

* 50\% of hay from Phoenix area (6 cuttings per year).

* Primarily Indian Reservations. 
Table 13

California, Phase II

Milk Production and Distribution

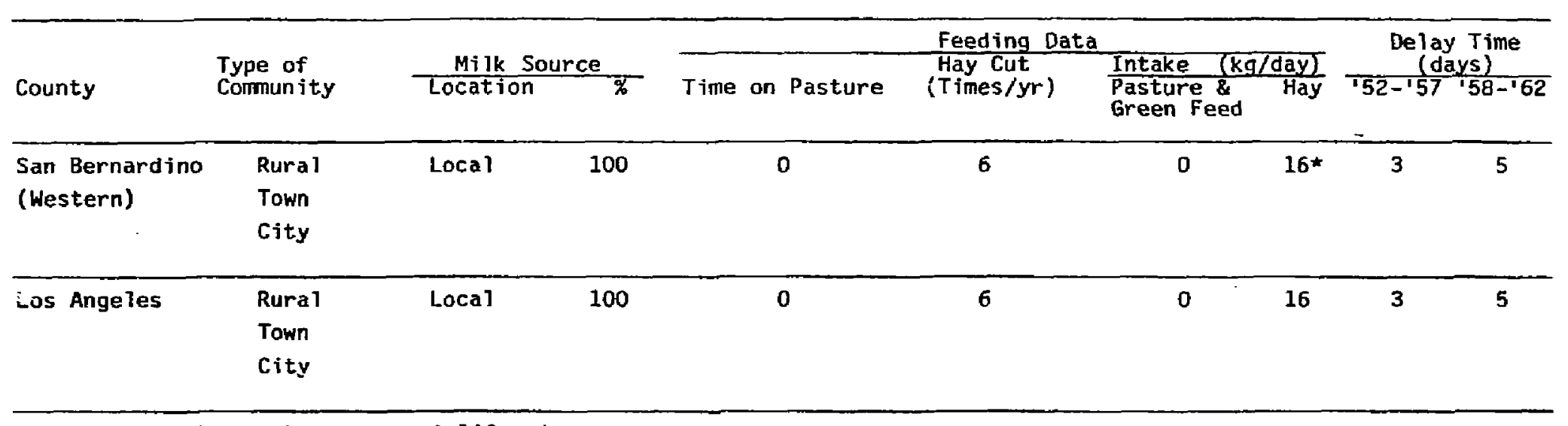

* Hay produced near Lancaster, California. 
Table 14

Colorado, Phase II

Milk Production and Distribution

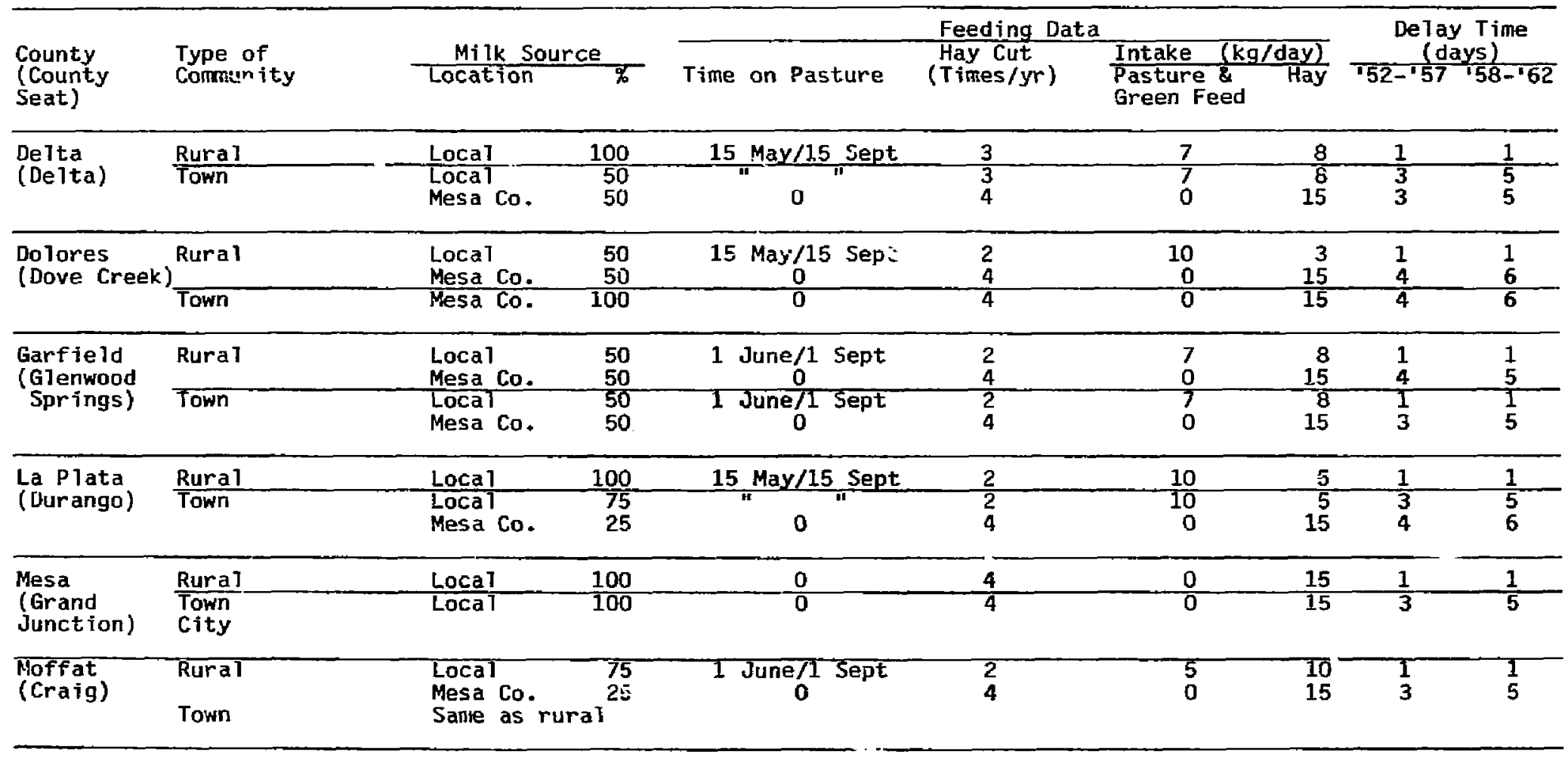


Table 14 (continued)

Colorado, Phase II

Mijk Production and Distribution

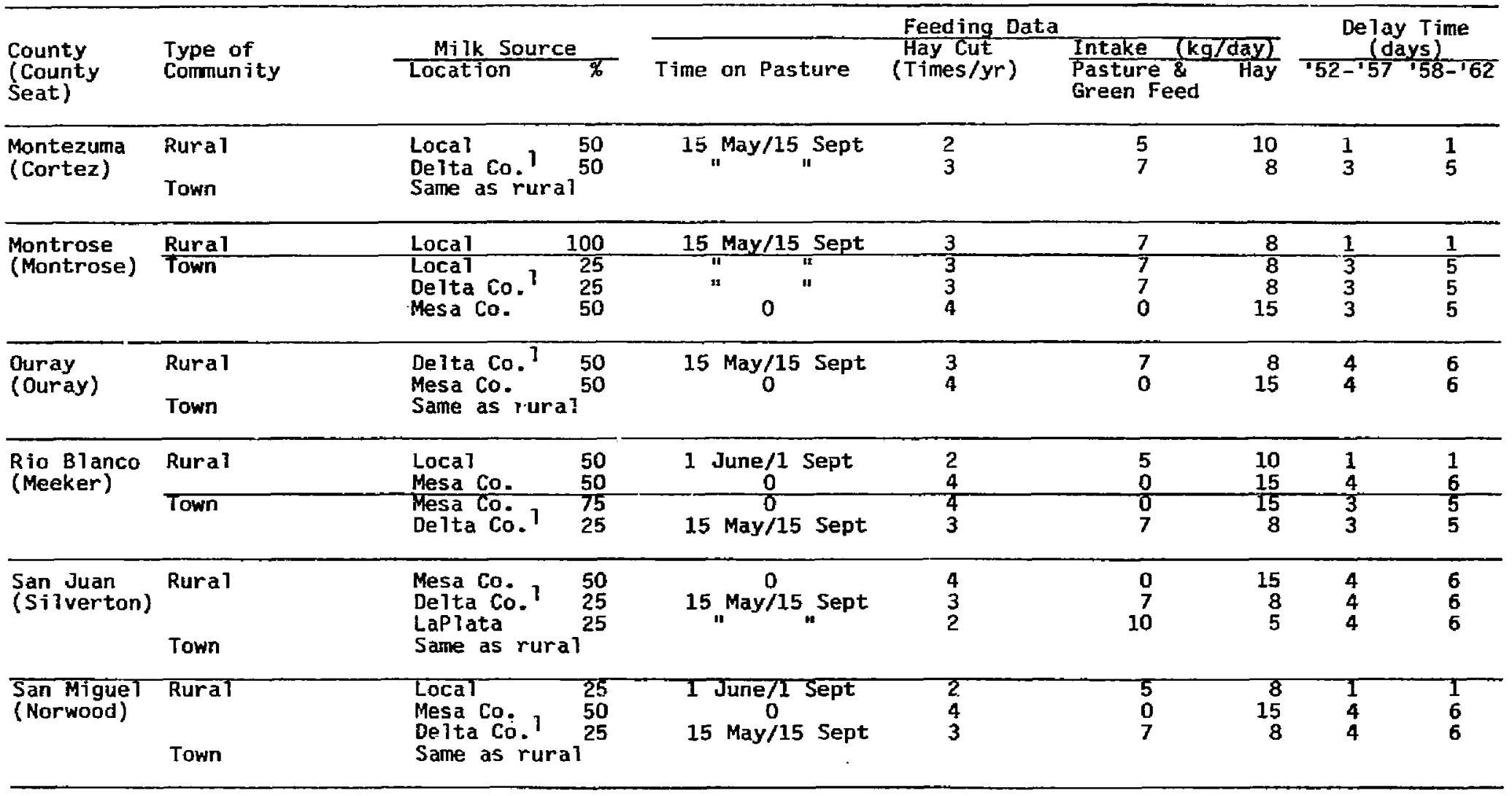

l=local milk 
Table 15

Idaho, Phase II

Milk Production and Distribution

\begin{tabular}{|c|c|c|c|c|c|c|}
\hline \multirow[b]{2}{*}{$\begin{array}{l}\text { County } \\
\text { (County } \\
\text { Seat) }\end{array}$} & \multirow{2}{*}{$\begin{array}{l}\text { Type of } \\
\text { Community }\end{array}$} & \multirow[b]{2}{*}{$\frac{\text { Milk Source }}{\text { Location }}$} & \multicolumn{3}{|c|}{ Feeding Data } & \multirow{2}{*}{$\begin{array}{c}\begin{array}{c}\text { Delay Time } \\
\text { (days) }\end{array} \\
52-157 \text { '58-'62 }\end{array}$} \\
\hline & & & Time on Pasture & $\begin{array}{l}\text { Hay Gut } \\
\text { (Times/yr) }\end{array}$ & $\begin{array}{l}\text { Intake }(\mathrm{kg} / \mathrm{day}) \\
\text { Pasture \& } \\
\text { Green Feed }\end{array}$ & \\
\hline
\end{tabular}

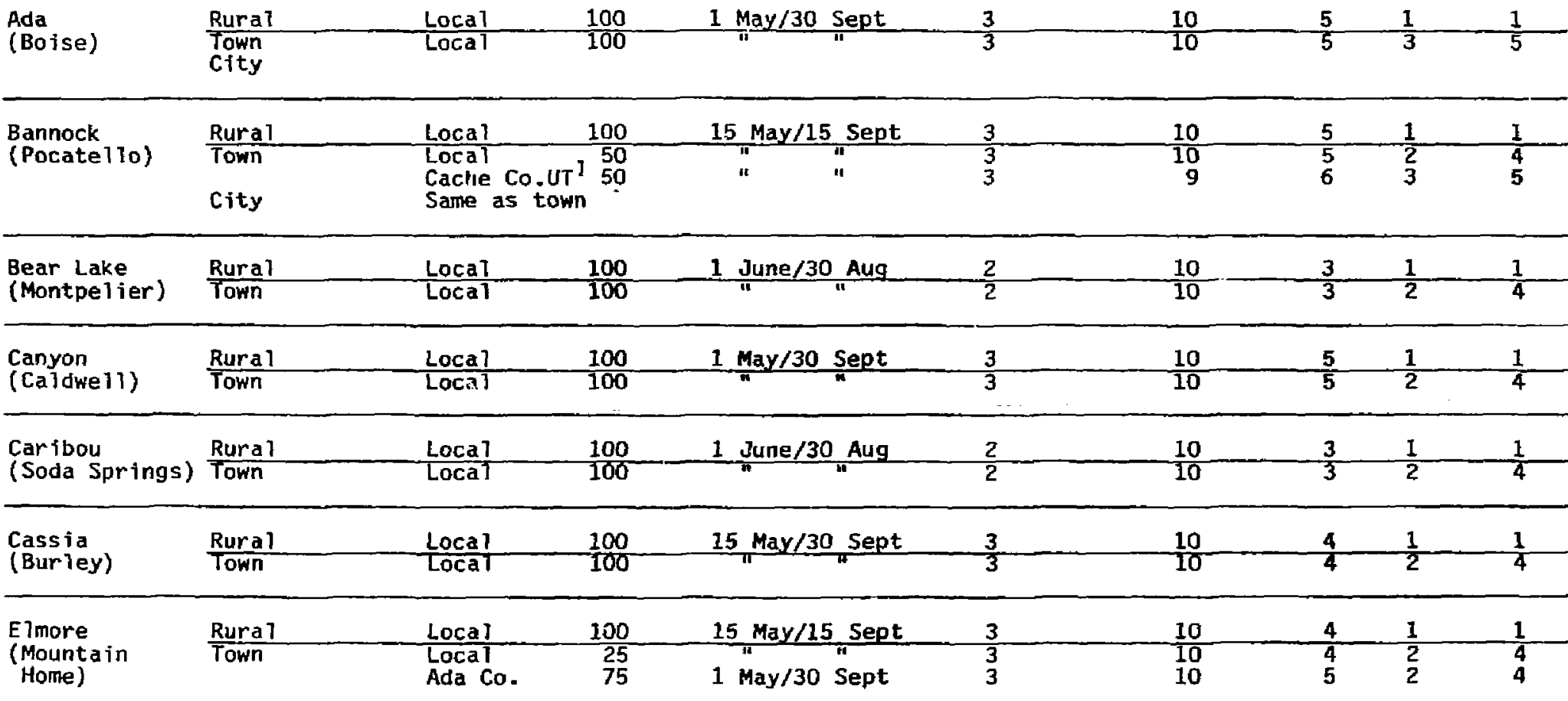

l=7ocal milk 
Table 15 (continued)

Idaho, Phase II

Milk Production and Distribution

\begin{tabular}{|c|c|c|c|c|c|c|c|c|c|}
\hline \multirow{2}{*}{$\begin{array}{l}\text { County } \\
\text { (County } \\
\text { Seat) }\end{array}$} & \multirow{2}{*}{$\begin{array}{l}\text { Type of } \\
\text { Community }\end{array}$} & \multicolumn{2}{|c|}{ Milk Source } & \multirow[b]{2}{*}{ Time on Pasture } & \multirow{2}{*}{$\begin{array}{l}\text { Feeding Data } \\
\text { Hay Cut } \\
\text { (Times/yr) }\end{array}$} & \multicolumn{2}{|c|}{ Intake (kg/day) } & \multicolumn{2}{|c|}{$\begin{array}{c}\text { Delay Time } \\
\text { (days) }\end{array}$} \\
\hline & & Location & $\bar{x}$ & & & $\begin{array}{l}\text { Pasture } 8 \\
\text { Green Feed }\end{array}$ & Hay & $.52-157$ & $58-162$ \\
\hline \multirow{3}{*}{$\begin{array}{l}\text { Frank lin } \\
\text { (Preston) }\end{array}$} & \multirow{3}{*}{$\frac{\text { Rura I }}{\text { Town }}$} & \multirow{3}{*}{$\begin{array}{l}\text { Local } \\
\text { Loca I } \\
\text { Cache Co. }\end{array}$} & 100 & 15 May/15 Sept & 3 & 10 & 4 & 1 & 1 \\
\hline & & & 50 & $=11$ & 3 & 10 & 4 & 2 & 4 \\
\hline & & & 50 & $n$ & 3 & 9 & 6 & 3 & 5 \\
\hline \multirow{2}{*}{$\begin{array}{l}\text { Gooding } \\
\text { (Gooding) }\end{array}$} & Rurat & Loca T & 100 & \multirow{2}{*}{${ }_{15}$ May/15 Sept } & 3 & 10 & 4 & 1 & 1 \\
\hline & Town & Loca 1 & 100 & & 3 & 10 & 4 & $\overline{2}$ & 4 \\
\hline \multirow{2}{*}{$\begin{array}{l}\text { Jerome } \\
\text { (Jerome) }\end{array}$} & Rura 1 & Loca 1 & 100 & \multirow{2}{*}{15 May/15 Sept } & 3 & \multirow{2}{*}{$\frac{10}{10}$} & \multirow{2}{*}{$\frac{4}{4}$} & \multirow{2}{*}{$\frac{1}{2}$} & \multirow{2}{*}{$\frac{1}{4}$} \\
\hline & Town & Local & 100 & & & & & & \\
\hline \multirow{2}{*}{$\begin{array}{l}\text { Lincoln } \\
\text { (Shoshone) }\end{array}$} & Rural & Loca 1 & 100 & \multirow{2}{*}{15 May $/ 15$ Sept } & 3 & 10 & 4 & \multirow{2}{*}{\multicolumn{2}{|c|}{$\frac{1}{4}$}} \\
\hline & Town & Local & 100 & & $\overline{3}$ & 10 & 4 & & \\
\hline \multirow{2}{*}{$\begin{array}{l}\text { Minidoka } \\
\text { (Rupert) }\end{array}$} & Rural & Local & 100 & \multirow{2}{*}{15 May $/ 15$ Sept } & 3 & 10 & 4 & \multirow{2}{*}{\multicolumn{2}{|c|}{$\frac{1}{4}$}} \\
\hline & Town & Local & 100 & & 3 & 10 & 4 & & \\
\hline \multirow{2}{*}{$\begin{array}{l}\text { Oneida } \\
\text { (Malad City) }\end{array}$} & Rural & Local & 100 & \multirow{2}{*}{15 May/15 Sept } & 3 & 10 & 4 & \multirow{2}{*}{\multicolumn{2}{|c|}{$\frac{1}{4}$}} \\
\hline & Town & Local & 100 & & 3 & 10 & 4 & & \\
\hline \multirow{2}{*}{$\begin{array}{l}\text { Owyhee } \\
\text { (Murphy) }\end{array}$} & Rural & Local & 100 & \multirow{2}{*}{15 May/15 Sept } & 3 & 10 & 4 & \multirow{2}{*}{\multicolumn{2}{|c|}{$\frac{1}{5}$}} \\
\hline & Town & Local & 100 & & 3 & 10 & 4 & & \\
\hline \multirow{2}{*}{$\begin{array}{l}\text { Power } \\
\text { (American } \\
\text { Fal1s) }\end{array}$} & Rura1 & Loca] & 100 & \multirow{2}{*}{$\frac{15 \text { May/15 Sept }}{\|}$} & 3 & 10 & 4 & 1 & 1 \\
\hline & Town & Laca? & 100 & & 3 & 10 & 4 & 2 & 4 \\
\hline Twins Falis & Rural & Local & 100 & 15 May/15 Sept & 3 & 10 & 4 & 1 & $I$ \\
\hline (Twins Falls) & Town & Local & 100 & & 3 & 10 & 4 & 2 & 4 \\
\hline
\end{tabular}

l=local mi lk. 
Table 16

New Mexico, Phase II

Mijk Production and Distribution

\begin{tabular}{|c|c|c|c|c|c|c|c|c|c|}
\hline \multirow{2}{*}{$\begin{array}{l}\text { County } \\
\text { (County } \\
\text { Seat) }\end{array}$} & \multirow[b]{2}{*}{$\begin{array}{l}\text { Type of } \\
\text { Community }\end{array}$} & & \multicolumn{4}{|c|}{ Feeding Data } & \multicolumn{2}{|c|}{ Detay Time } \\
\hline & & $\frac{\text { Milk Sour }}{\text { Location }}$ & $\frac{\mathrm{ce}}{\%}$ & Time on Pasture & $\begin{array}{l}\text { Hay Cut } \\
\text { (Times/yr) }\end{array}$ & $\begin{array}{l}\text { Intake (k } \\
\text { Pasture \& } \\
\text { Green Feed }\end{array}$ & $\frac{\text { gg/day }}{\text { Hay }}$ & '52-' & 5) \\
\hline Mckintey & Rural & Local & 100 & 15 May/15 Sept & 3 & 5 & 10 & 1 & 1 \\
\hline \multirow{4}{*}{ (Farmington) } & Town & Loca 1 & 50 & 1 May/30 Sept & 3 & 5 & 10 & 3 & 5 \\
\hline & & Albuquerque? & 25 & 0 & 4 & 0 & 15 & 4 & 6 \\
\hline & & LaPlata $\mathrm{Co}_{0}{ }^{1}$ & 25 & 15 May/15 Sept & 3 & 5 & 10 & 3 & 5 \\
\hline & City & Same as town & & & & & & & \\
\hline \multirow{4}{*}{$\begin{array}{l}\text { San Juan } \\
\text { (GaTlup) }\end{array}$} & Rura1 & Albuquerque $^{1}$ & 75 & 0 & 4 & 0 & 15 & 4 & 6 \\
\hline & & Farmington? & 25 & 1 May/30 Sept & 3 & 5 & 10 & 3 & 5 \\
\hline & Town & Same as rural & & & & & & & \\
\hline & City & Same as town & & & & & & & \\
\hline
\end{tabular}

l=local milk 
Table 17

Oregon. Phase II

Milk Production and Distribution

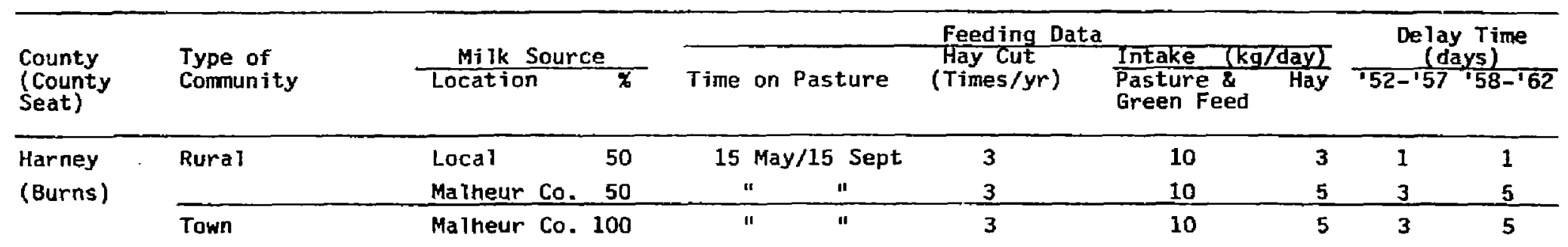

$\begin{array}{lllllllll}\text { Malheur } & \text { Rural } & \text { Local } & 100 & 15 \text { May/15 Sept } & 3 & 10 & 3 & 1 \\ \text { (Ontario) } & \text { Town } & \text { Local } & 100 & * & \text { " } & 3 & 10 & 3\end{array}$


Table 18

Wyoming, Phase II

Milk Production and Distribution

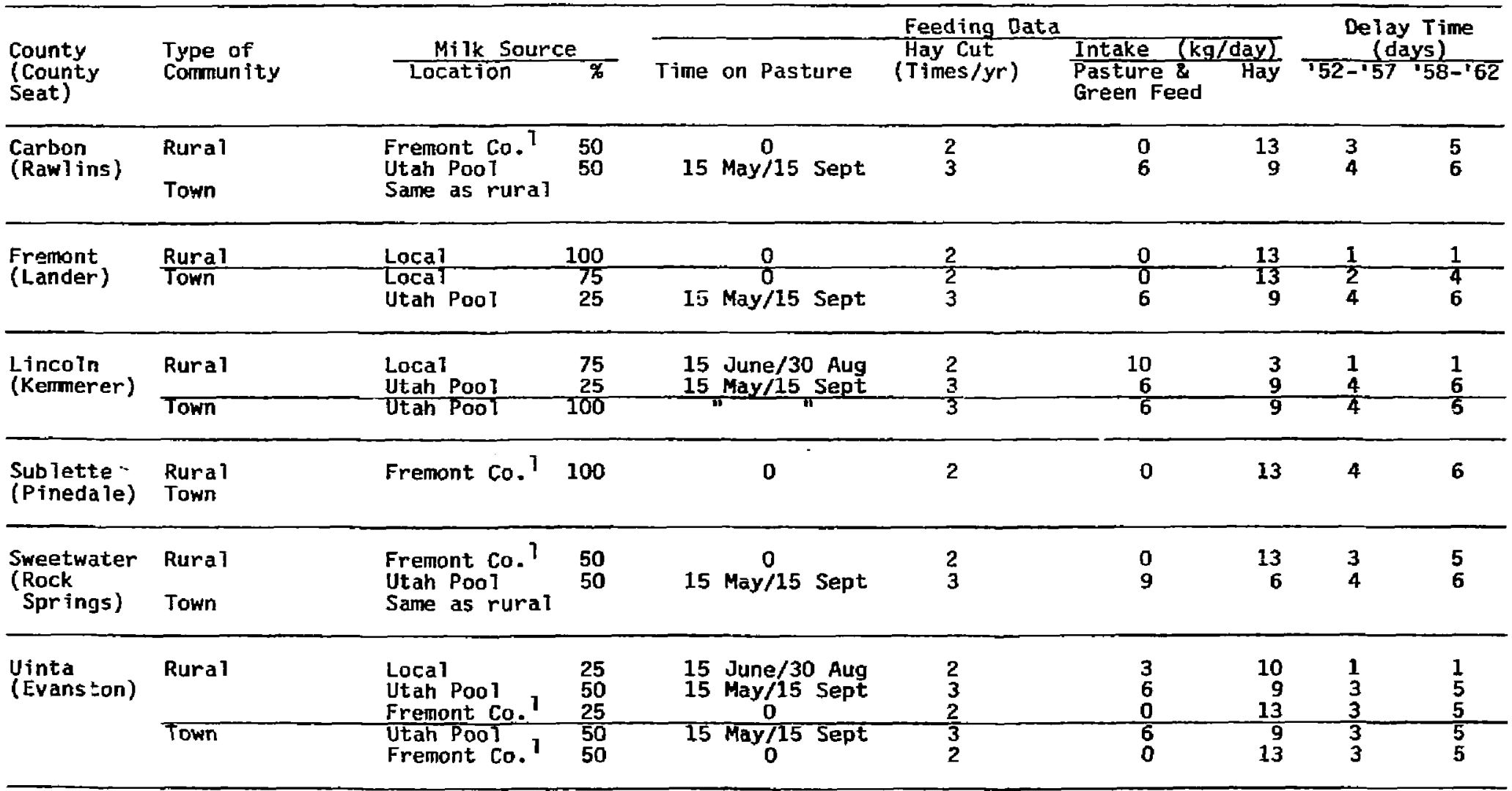

l= Tocal mf Ik. 


\section{APPEWDIX 1.}

\section{Some Characteristics of Dairy Food Technology of Significance to Food Chain Assessment}

M1lk is an important vector to man for several radionuclides after nuclear fallout deposition. In addition to fluid milk, which is discussed in this paper, a number of other dairy products can be a source of radionuclide contamination in the human diet. These products include cottage cheese, yogurt, ice cream, hard cheeses, butter, evaporated milk and dried sk im milk. The per capita consumption of these products is lower than for fluid milk but the solids in these products are more concentrated than milk, thus radionuclide intake from these products could be significant.

Information about the distribution or concentration of radionuclides between the milk fractions and thus of the dairy products is necessary for dose assessments. Furthemore, information about radionuclide concentrations in different dairy products can be of value for preparing a strategy to reduce human exposure in the case of nuclear releases. Studies of distribution in milk components has been limited to Cs, I and Sr, but these nuclides are the most important to dose assessment.

Milk is a complex colloidal solution of protein and fat suspended in water. Milk processing depends upon separation of fat and/or denaturation and coagulation of protein.

Pure milk fat accumulates little radioactivity, thus cream and butter have a smail percentage of the ${ }^{131_{I}},{ }^{90} \mathrm{Sr}$, and ${ }^{137} \mathrm{Cs}$ found in milk (Table A-1). Only about $15 \%$ of the 131 In milk is found in hard cheese (Lengemann and Swanson, 1957). However, because of the short haif life 
and normal storage times for butter and hard cheese, these products are not important in the foodchain transfer of ${ }^{131}$ I. The oniy important carriers of this nuclide are whole milk, skim milk, cottage cheese, yogurt, and, to a lesser extent (because of storage time), ice cream. The recovery of ${ }^{131}$ I from cottage cheese and yogurt does not seem to have been studied but knowledge of the process would indicate a higher percentage than for regular or hard cheeses. The cottage cheese process produces about $15 \mathrm{~kg}$ from $100 \mathrm{~kg}$ of milk while cheddar cheese produces $10 \mathrm{~kg}$ per $100 \mathrm{~kg}$ (Darrell Deane, Fort Collins, Co, personal communication). The studies of Reavey and Baratta (1966) indicated losses of ${ }^{131_{I}}$ in evaporation and drying of milk. However, because of generally long storage times and lower consumption, these products are not significant sources of radioiodine.

The data presented in Table A-2 indicate insignificant percentages of $\mathrm{Cs}_{\mathrm{S}}$ and $\mathrm{Sr}$ in butter, but higher percentages in cream, cottage cheese, and cheddar-type cheese. The data of Demott and Cragle (1960) also indicate that about $50 \%$ of the ${ }^{89} \mathrm{Sr}$ in whole milk was recovered in cheddar cheese and negligible anounts in crean. Similar results were reported by Buma and Meerstra (1964). The resuits of Reavey and Baratta (1966) indicate large differences between types of cottage cheese and higher percentages recovered than indicated by Lengemann (1962). The ${ }^{90} \mathrm{Sr}$ and ${ }^{137} \mathrm{Cs}$ recovery in heavy cream are much higher than reported in other studies. There is no apparent explanation for the differences. Although losses of nuclides will occur in cheese making, the concentration per $\mathrm{kg}$ will be higher than in milk because of the higher solids percentage. The same is true of dried milk which contained ten times more ${ }^{137}$ Cs per $\mathrm{kg}$. Evaporated milk also contains higher nuclide 
concentrations than fresh milk when first prepared, even though some ${ }^{131} I$ is lost in evaporation (Reavy and Baratta, 1966). Ice cream is a complex product made of cream, ory milk solids, sugar and other additives. The volume of ice cream may be $50 \%$ air. Ice cream probably contains $50-75 \%$ of the nuclides in milk on a weight basis, but actual comparisons were not found in the literature surveyed. Yogurt is a dairy product of increasing significance but it was not important in the 1951-1962 period. Yogurt is essentially coagulated whole milk and thus no partitioning of nuclides would be expected. The elapsed time from production on the farm to consumption, which is largely a reflection of the shelf life of products, is indicated in Table A-3 for some dairy products. 
Table A-1. Distribution of fallout radionuclides from whole milk to milk products (Lagoni, Paakkola and Peters, 1963).

\begin{tabular}{lccc}
\hline & \multicolumn{3}{c}{ Percent } \\
\cline { 2 - 4 } Product & 100 & 100 & 100 \\
\hline Whole Milk & 92 & 84 & 85 \\
Skim Milk & 8 & 16 & 15 \\
Cream & 2 & 2 & 1.5 \\
Butter & & & \\
\hline
\end{tabular}


Table A-2. Recovery in derived dairy products of ${ }^{137} \mathrm{Cs}$ and radiostrontium added to whole milk.

\begin{tabular}{|c|c|c|c|c|c|}
\hline \multirow[b]{2}{*}{ Product } & \multicolumn{4}{|c|}{ Percent Recovered } & \multirow[b]{2}{*}{ Reference } \\
\hline & $\overline{137} \mathrm{Cs}$ & $85 \mathrm{sr}$ & ${ }^{90} \mathrm{Sr}$ & $\overline{89} \mathrm{Sr}$ & \\
\hline Butter & 0.03 & 0.06 & & & Lengemann, 1962 \\
\hline Heavy Cream & 60 & & 32 & & Reavy \& Baratta, 1966 \\
\hline Cheddar Cheese & 7.7 & 49 & & & Lengemann, 1962 \\
\hline Cheddar Cheese & & & & 50 & Demott \& Cragle, 1960 \\
\hline Cottage Cheese & 1.1 & 2.7 & & & Lengemann, 1962 \\
\hline $\begin{array}{l}\text { Cottage Cheese } \\
\text { (1arge curd) }\end{array}$ & 30 & & 46 & & Reavy \& Baratta, 1966 \\
\hline $\begin{array}{l}\text { Cottage Cheese } \\
\text { (smal1 curd) }\end{array}$ & 15 & & 22 & & Reavy \&aratta, 1966 \\
\hline
\end{tabular}


Table A-3. Elapsed time between production and consumption.

\begin{tabular}{|c|c|c|}
\hline \multirow[b]{2}{*}{ Product } & \multicolumn{2}{|c|}{ Elapsed Time (Days) } \\
\hline & Range & Made \\
\hline On-Farm Consumption of milk & $12-36 \mathrm{hrs}$ & 24 hrs \\
\hline $\begin{array}{l}\text { Milk home dei ivery from dairy } \\
\text { Early 1950s } \\
\text { Late 1950s }\end{array}$ & $\begin{array}{l}2-5 \text { days } \\
4-15 \text { days }\end{array}$ & $\begin{array}{l}4 \text { days } \\
6 \text { days }\end{array}$ \\
\hline $\begin{array}{c}\text { Cottage Cheese } \\
\text { Early 1950s } \\
\text { Late 1950s }\end{array}$ & $\begin{array}{l}3-12 \text { days } \\
4-15 \text { days }\end{array}$ & $\begin{array}{l}5 \text { days } \\
7 \text { days }\end{array}$ \\
\hline Ice Cream & 4-45 days & 10 days \\
\hline $\begin{array}{l}\text { Cured Cheese (All cheese except } \\
\text { cottage cheese) }\end{array}$ & $60-1000$ days & 100 days \\
\hline
\end{tabular}




\section{References}

Buma, T. J. and J. Meerstra. 1964. Transfer of radiostrontium from milk to cheese and whey. Nature 202:310-311.

Demott, B. J. and R. G. Cragle. 1960. Strontium in milk III. Distribution in cream, skim milk, cheddar cheese and whey. J. Dairy Sci. 42:925-930.

Lagoni, H., O. Paakkola and K. H. Peters. 1963. Uber die verteilung der radionuklide des fallouts (90-5r. 131-I and 137-cs) in naturlich kontaminierter milch. Naturwissenchaften 50:495-496.

Lengemann, F. H. and E. W. Swanson, 1957. A study of the secrestion of iodine in milk of dairy cows, using daily oral doses of $13 \mathrm{I}, \mathrm{J}$. Dairy Sci, 40:216.

Lengemann, F. W. 1962. Distribution of radiostrontium and radiocesium in milk and milk products. J. Dairy Sci. 45:538-539.

Reavy, T. C. and E. J. Baratta. 1966. Comparison of Strontium-90, ludine-131 and Cesium-137 in milk and milk products. Rad. Health Data and Reports, Vol. 7, p. 215. 


\section{APPEMDIX 2}

\section{Sources of Information by State}

\section{Utah}

The report entitled "Dairy Production and Pasture Utilization by

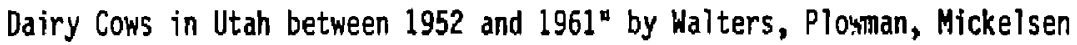
and Zaugg, 1985 (Utah State University, Logan, UT 84322), provided data for feeding practices in Utah. This report was produced as a Subcontract to Colorado State University.

Information on milk sources and distribution was obtained primarily from interviews with former managers of the three dairy cooperatives and from Rondo Christianson, Professor of Economics at Utah State University. Former managers included Glen Garrett, Kaysville, Utah (Weber Central); Bill Godfrey, Sandy, Utah (Hi-Land Dairy); and Vern Bingham, Thornton, Colorado (Federated Producers). As a result of several visits to Utah, discussions were held with a number of other dairy experts. These included Dean Plowman, Lloyd Hunsaker, Charlie Mickelson, Tony Ernstrom, Anson Call, and George Stoddard, all from Utah State University at Logan. We also visited with Robert Gardner and James Wiltbank, Department of Animal Science, Brigham Young University, Provo.

County extension agents who provided information included Grant Esplin, Beaver; Wallace Sjoblom, Ogden; Lloyd Smith, Morgan Cuunty; Wayne Rose, Salt Lake City; and Clare Accord, Salt Lake City. 


\section{Mevada}

A primary source of data for Nevada was the report entitled "The Milk Distribution System in Mevada, 1950 to 1965" by James R. Garrett, (University of Nevada, Reno, NY 89557), which was produced as a subcontract to Colorado State University. These data were augmented by trips by Lane Ely and Gerald Ward and conversations with Verle Bohman of the University of Nevada.

\section{Arizona}

Information for Arizona was obtained from interviews with staff of the University of Arizona, Tucson, including A1 Lane, Extension Beef Crttle Specialist; Ralph van Zandt, Extension Dairy Specialist (retired); Dr. Thomas Wegner, Professor of Dairy Physiology; and William Brechan, County Extension Agent, Flagstaff (retired).

\section{California}

Information for eastern California was obtained from Gary Giacomini, a rancher rear Bishop, Clem Pelissier, who was an extension dairy specialist in California for 35 years and Dr. John Edwards, formerly a professor at Fresno State University, now at Colorado State University.

Information on milk marketing in California was obtained from Leland Lockhard, Chief of the Milk and Dairy Control Division for the State of California at Sacramento. 


\section{Colorado}

Those who contributed information relative to colorado included Richard Woodfin, Retired County Extension Agent; Vernon Cornforth, County Extension Agent; and Duane Clymer, Manager, Clymer's Dairy; all from Grand Junction. Other sources included Virgil Diffendaffer, Dairy Farmer, Palisades; James Gregory, Retired County Extension Agent, Craig; George Wetterich, Dairy Farmer, Cedaredge; Ben Sheldon, Former Dairyman, Paonia; Sheldon Slade, Dairy Farmer, Hesperus; and Robert McCaw, Dairy Farmer, Durango. In addition, the senior author had considerable personal knowledge about Colorado practices.

\section{Idaho}

Sources of information for Idaho were retired agricultural extension personnel, especially George Cleveland, a retired extension dairyman for the University of Idaho. Mr. Cleveland traveled with G. M. Ward and visited several counties in eastern Idaho where interviews were held with farmers and ccunty extension agents.

\section{New Mexico}

Sources of information included Vern Swanson, former extension agent at Gallup; Dudley Price, President, Price Dairy, Albuquerque; 0. J. Adams, former Milk Marketing Administrator, A]buquerque; and Joe Wallace, Department of Animal and Range Science, New Mexico State University, Las Cruces. 


\section{Oregon}

Sources of information inciuded Robert Raleigh, Director of Squaw Butte Research Station, Burns; Dr. Holyoke Adams, Extension Dairy Specialist, Oregon State University, Corvallis; and George Cleveland, former Extension Dairy Specialist, University of Idaho, Boise.

\section{Hyowing}

Sources of information included Lyle Bang, former County Extension Agent, Riverton; Bill Bagley, former County Extension Agent, Afton; Jess Stern, former Dairy Commissioner, State of Hyoming; and Daryl Dean, former Professor of Dairy Science, University of Wyoming. 